NBER WORKING PAPER SERIES

\title{
MONEY AND VELOCITY DURING FINANCIAL CRISES: FROM THE GREAT DEPRESSION TO THE GREAT RECESSION
}

\author{
Richard G. Anderson \\ Michael Bordo \\ John V. Duca \\ Working Paper 22100 \\ http://www.nber.org/papers/w22100
}

\author{
NATIONAL BUREAU OF ECONOMIC RESEARCH \\ 1050 Massachusetts Avenue \\ Cambridge, MA 02138 \\ March 2016
}

We thank Jens Christensen, Benjamin Doring, Samuel Reynard, and participants at the 2014 Paul Woolley Conference in Sydney, 2015 FMA European Conference, 2015 Bundesbank Workshop on Central Banks and Crises-Historical Perspectives, the 2015 Swiss Society for Financial Market Research Conference, and the 2015 conference, Large-Scale Crises: 1929 vs. 2008 for suggestions and comments. We thank J.B. Cooke and Elizabeth Organ for excellent research assistance. This paper reflects our intellectual debt to many monetary economists, especially Milton Friedman, Stephen Goldfeld, Richard Porter, Anna Schwartz, and James Tobin. The views expressed are those of the authors and are not necessarily those of the Federal Reserve Banks of Dallas and St. Louis, the Federal Reserve System, or the National Bureau of Economic Research. Any errors are our own.

At least one co-author has disclosed a financial relationship of potential relevance for this research. Further information is available online at http://www.nber.org/papers/w22100.ack

NBER working papers are circulated for discussion and comment purposes. They have not been peer-reviewed or been subject to the review by the NBER Board of Directors that accompanies official NBER publications.

(C) 2016 by Richard G. Anderson, Michael Bordo, and John V. Duca. All rights reserved. Short sections of text, not to exceed two paragraphs, may be quoted without explicit permission provided that full credit, including $(\odot$ notice, is given to the source. 
Money and Velocity During Financial Crises: From the Great Depression to the Great Recession Richard G. Anderson, Michael Bordo, and John V. Duca

NBER Working Paper No. 22100

March 2016

JEL No. E41,E50,G11

$\underline{\text { ABSTRACT }}$

This study offers a single, consistent model that tracks the velocity of broad money (M2) since 1929, including the Great Depression, the global financial crisis, and the Great Recession. The model emphasizes the roles of changes in uncertainty and risk premia, financial innovation, and major banking regulations. Our findings suggest an enhanced role of a broad, liquid money aggregate as a policy guide during crises and their unwinding. Following crises, policymakers face the challenge of not only unwinding their balance sheet so as to prevent excess reserves from fueling a surge in M2, but also countering a fall in the demand for money as risk premia return to normal amid velocity shifts stemming from relevant financial reforms.

Richard G. Anderson

Fedeeral Reserve Bank of St. Louis

St.Louis , Mo 63101-3716

rganderson@alum.mit.edu

Michael Bordo

Department of Economics

Rutgers University

New Jersey Hall

75 Hamilton Street

New Brunswick, NJ 08901

and NBER

bordo@econ.rutgers.edu
John V. Duca

Federal Reserve Bank of Dallas

2200 North Pearl Street

Dallas, TX 75201

John.V.Duca@dal.frb.org 


\section{Introduction}

The Great Depression and the Great Recession are acknowledged as the defining American financial crises of the past century. ${ }^{1}$ At least since Bagehot, it has been wellunderstood that financial crises require aggressive central bank intervention. Crises are accompanied by two mutually self-reinforcing factors that reduce economic activity, flights-toliquidity and increases in risk premia. Both are evidenced by increased demand for safe assets, including government bonds, central bank liabilities, and government-insured financial institution liabilities. A central bank typically responds by expanding its balance sheet via asset purchases and/or lending. When the crisis passes, the central bank's task is to remove excess liquidity by shrinking its balance sheet at an appropriate pace, a task made difficult by portfolio shifts away from low-yielding highly liquid assets and reversion of risk premia to more normal levels. A clear dynamic model that tracks past crises can be a useful guide for such policies.

This paper contributes a dynamic empirical model of the demand for broad, liquid money that well-fits the two preeminent American financial crises of the past century, and also welltracks the behavior of broad money during the years between crises, including the early-2000s period of "missing money." The analysis, by treating carefully innovations in financial intermediation and time-variation in financial-asset risk premia, makes visible a dynamic, nonlinear interaction in which lower transaction costs (particularly for bond and equity mutual funds) encourage more rapid portfolio rebalancing in response to shifting risk premia. ${ }^{2}$

Technically, our analysis extends, to early historical periods, the models of broad money demand developed by Anderson and Duca (2013) that, by permitting velocity to respond to

\footnotetext{
${ }^{1}$ In a related paper, Bordo and Haubrich (2012) discuss other American financial crises.

${ }^{2}$ Two assets are "extremely close" as media of exchange if the transaction cost of exchanging one for the other is de minimis. By explicitly measuring the economically meaningful "distance" between assets with out-of-pocket costs, we reject the assertion that this distance is well-measured by differences in assets' market yields (e.g., Barnett, 1980).
} 
higher uncertainty during crisis periods and later revert to normal levels, reconcile the low inflation, weak nominal income growth, and moderately robust broad money growth of the recent economic recovery. ${ }^{3}$ To include the Great Depression, we extend estimates of mutual fund costs back to the 1920s and develop pre-WWII measures of own rates of return for M2. By also controlling for shifts in risk premia and relevant financial innovations, our framework provides a statistically sound and internally consistent way of modeling money demand in both the short- and long-runs. The quality of our results is illustrated in Figure 1 by our model's ability to track equilibrium M2 velocity since the early 1930s. ${ }^{4}$

\section{Figure 1: M2 Velocity Tracked by Model Incorporationg Financial Innovation and Risk Premia}

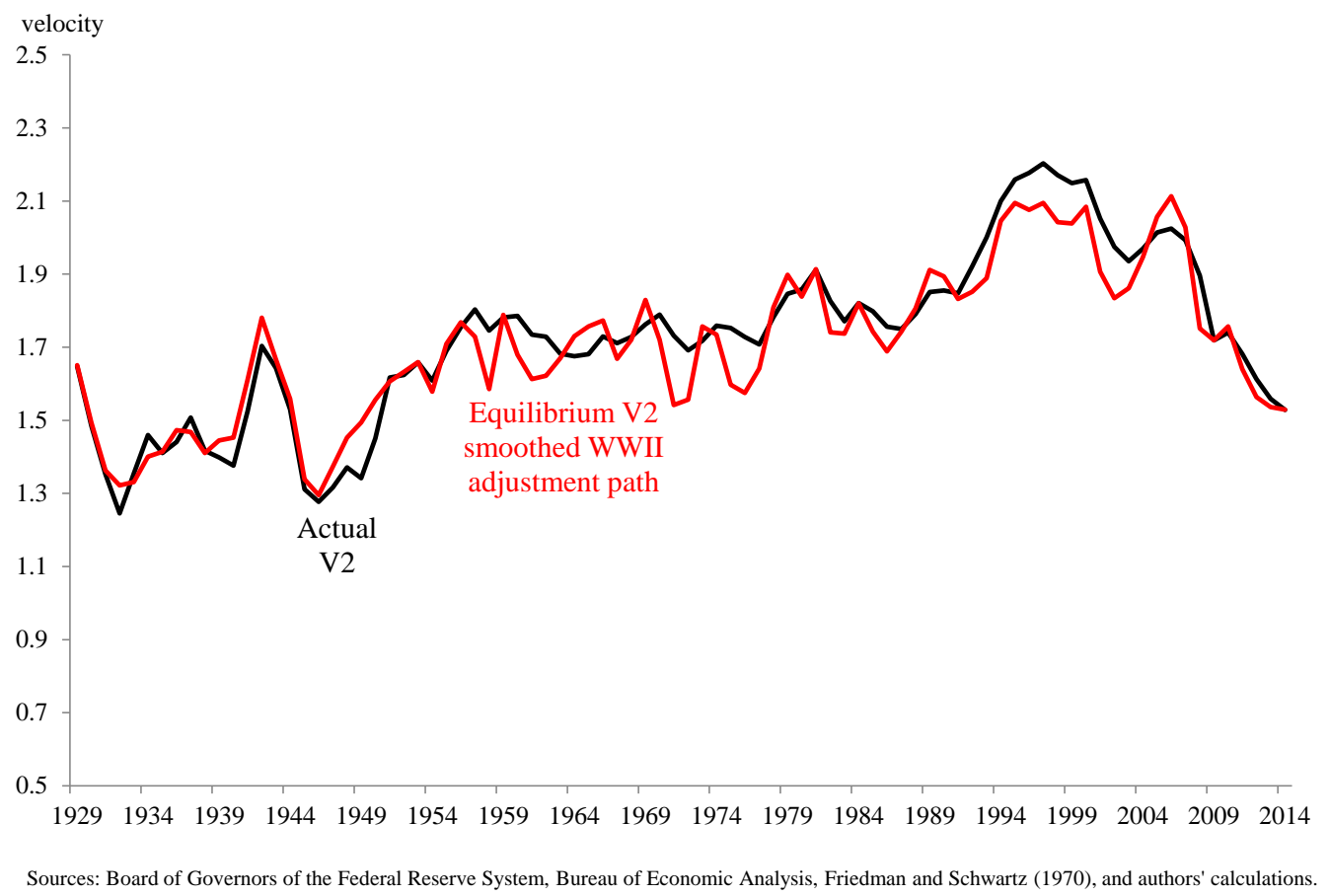

\footnotetext{
${ }^{3}$ By inducing shifts in the neutral Wicksellian real rate, financial innovations and frictions pose serious challenges for gauging monetary policy with the Taylor-Rule. Indeed, Barsky, Justiniano, and Melosi (2014) estimate that the neutral real rate has varied in a 7 1/2 percent range since 1990. Tracking real interest rates also entails the difficulty of measuring inflation expectations since the 1930s (Jalil and Rua, 2015), which our framework circumvents.

${ }^{4}$ Figure 3 and our models use various controls to address money demand shifts associated with World War II.
} 
History shows that money demand retreats in response to falling risk premia and increasing opportunity costs vis-à-vis bond yields. Resulting increases in velocity amplify broad money growth and, mixed with the effects of financial reform, challenge a successful unwinding. A successful exit strategy must seek, via reductions in the monetary base, to temper the pace of broad money growth going forward relative to a money demand that is decreasing toward more normal levels as risk premia revert to typical levels. Although the Federal Open Market Committee (FOMC) in October 2014 ceased buying net securities under its Large Scale Asset Purchase program, it has not started reducing its balance sheet: total securities holdings in the week ending January 27,2016 , were $\$ 4,236,838$ vs. $\$ 4,223,920$ in the week ending October 29 , $2014 .^{5}$

To establish these and other results, this study is organized as follows. Section 2 reviews the impact of earlier crises on risk premia and money demand, emphasizing the Great Depression and the Great Recession. Section 3 reviews previous studies of money demand. Section 4 discusses the specification of our empirical model, and Section 5, the variables we use to measure mutual fund loads and market risk premia. Section 6 presents our estimated dynamic error correction model and some simulations of velocity and nominal GDP. Section 7 draws some conclusions.

\section{Disruptions of Financial Markets Circa Financial Crises}

Risk premia and the velocity of broad money change rapidly and by large amounts circa crises. Impacts of the Great Depression and the Great Recession are evident in risk premia, measured as the spread between yields on Baa corporate bonds and 10-year Treasury bonds

\footnotetext{
${ }^{5}$ The FOMC voted to maintain its asset holdings at the then-current level by rolling over maturing Treasuries into new issues and reinvesting principal payments on agency debt and mortgage securities into similar securities.
} 
(Figure 2) and in velocity (Figure 3). As the Great Depression abated, for example, risk premia fell and velocity returned to more typical levels. More recently, from year-end 2006 to 2014, broad money growth, nominal GDP growth, and inflation (GDP chain price index) increased, respectively, at 6.5, 2.9, and 1.6 percent annual rates. The pace of broad money growth, albeit 6 1/2 percent, has accompanied relatively low nominal GDP growth and inflation. ${ }^{6}$ Many factors contributed to this outcome, including increased banking regulation, flight-to-quality effects, the expansion of bank reserves, and a plunge in the money multiplier reflecting, as emphasized by Brunner and Meltzer (1966), both the lending activity of banks and the demand by households and firms to hold deposits at banks. Combining these factors, we attribute the decrease in broad money velocity to heightened risk premia and a decreasing opportunity cost of broad money relative to bonds. $^{7}$

While the historical paths of inflation/deflation and unemployment (Figures 4 and 5) suggest that Federal Reserve performed better in preventing deflation and quelling high unemployment during the Great Recession than in the Great Depression, high unemployment from 2008 to 2012 suggests a shortfall in meeting the full employment objective part of the Federal Reserve's dual mandate. Indeed, despite the Federal Reserve's efforts, the Great Recession has seen a shortfall in nominal demand (Figure 6) even though M2 increased solidly during the Great Recession (except for 2010) while contracting dramatically during the Great Depression (Figure 7). At first pass, robust M2 growth during the recent crisis suggests that monetary policy provided adequate liquidity. Such an inference, however, requires comparing money demand with money supply: in crises, the demand for liquidity—such as for the safe assets in M2—surges.

\footnotetext{
${ }^{6}$ Some (e.g., Svensson, 2009) argue that the recovery will remain slow so long as broad money growth is not strong. ${ }^{7}$ Friedman and Schwartz (1963) also emphasize the Fed's failure to protect the stability of the financial system, something which the Bernanke-led Fed largely avoided.
} 


\section{Figure 2: Financial Market Risk Premium Circa Two Financial Crises}

(Baa - Treasury bond yield spread)

Index $=1$

in 1929, 2006

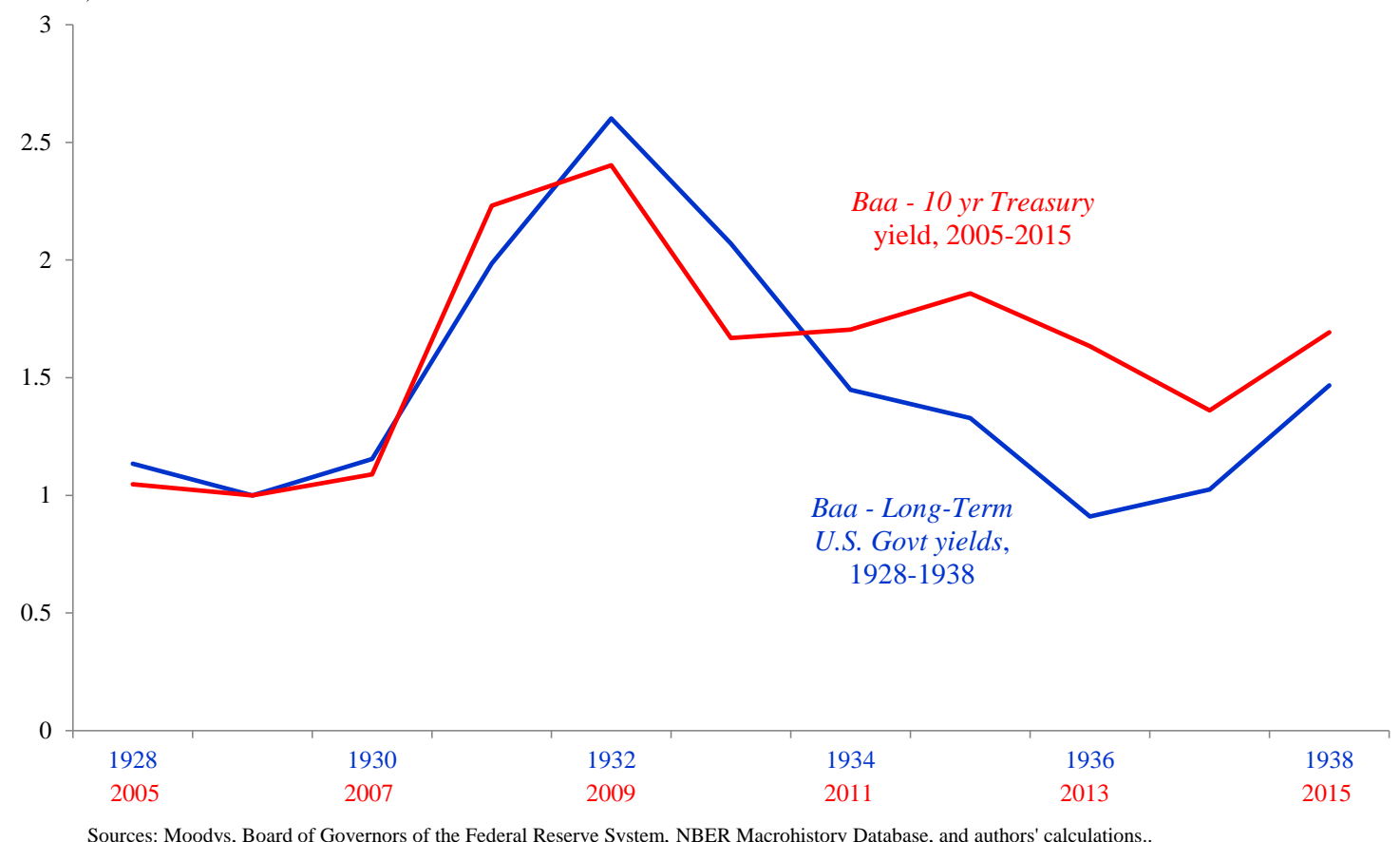

Figure 3: M2 Velocity Circa Two Financial Crises

Index $=1$

(normalized to equal 1 in 1929 and in 2006)

in 1929, 2006

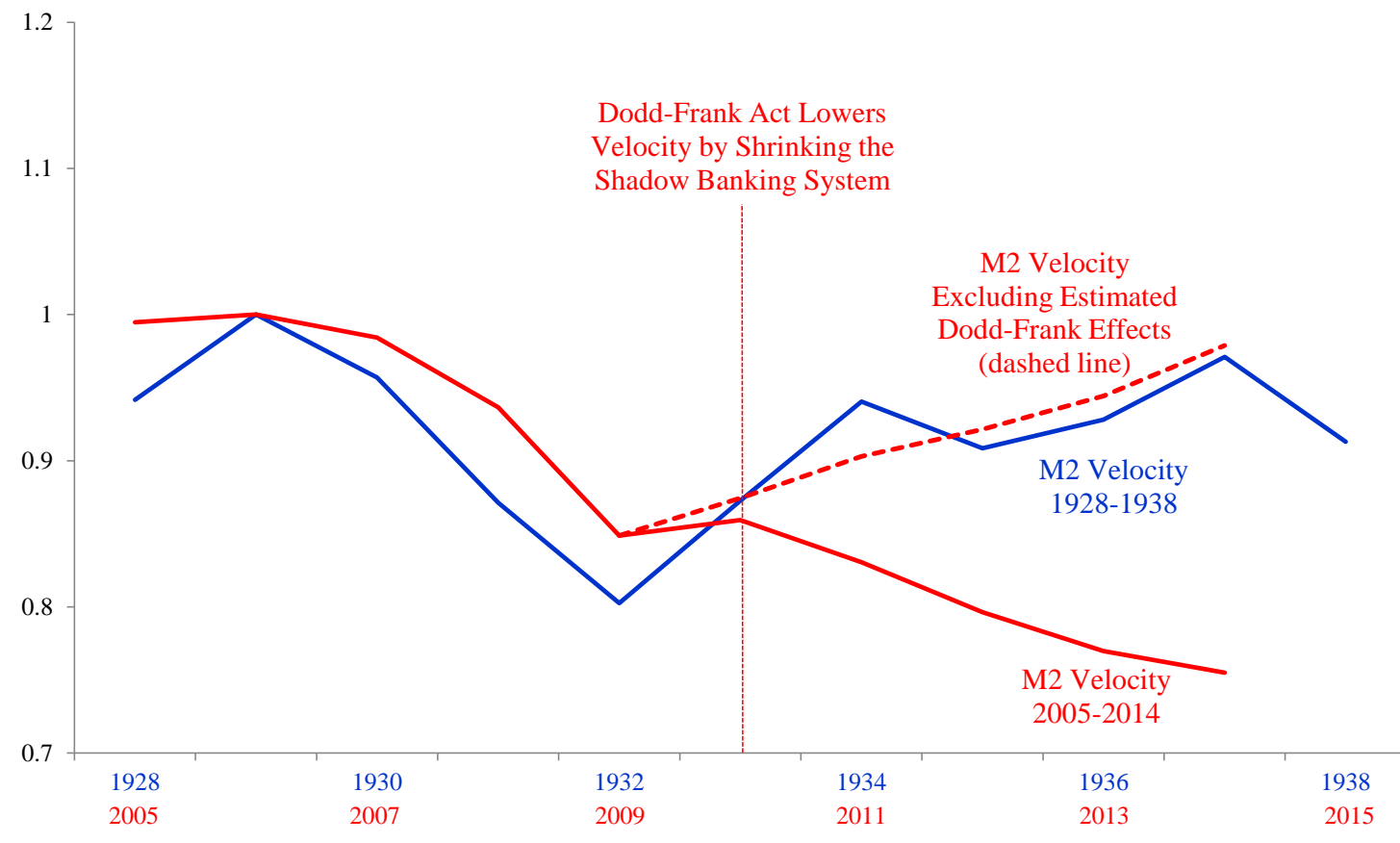

Sources: Bureau of Economic Analysis, Board of Governors of the Federal Reserve System, Friedman and Schwartz (1970), and authors' calculations. 
Figure 4: In Contrast to the Great Depression, the Fed Prevents Substantial Deflation in the Great Recession

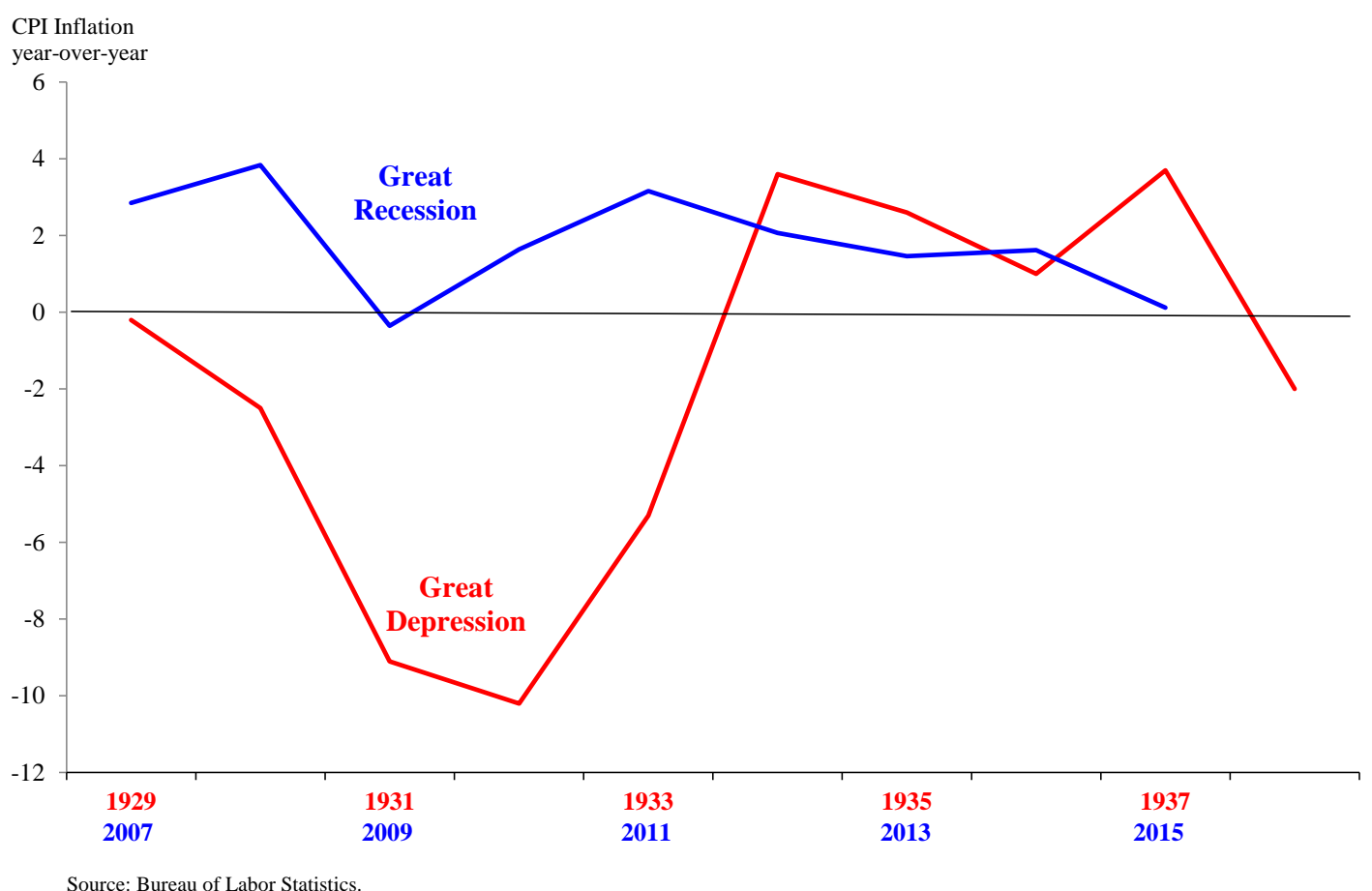

Figure 5: Unemployment in the Great Depression Rose Far More than in the Great Recession

Civilian Unemployment Rate percentage points ${ }^{1}$

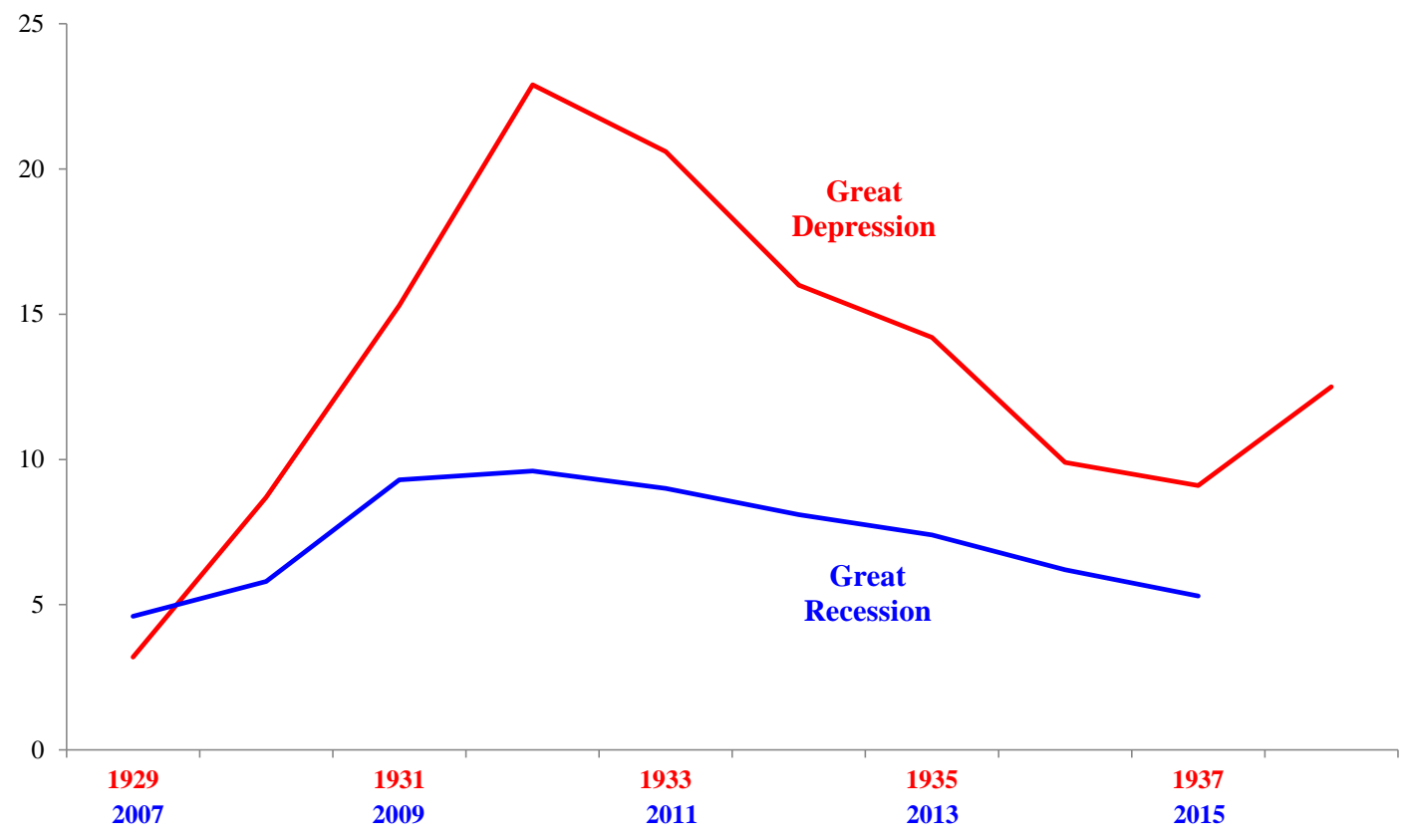

Sources: Bureau of Labor Statistics and Darby (1976).. 
Figure 6: The Fed Better-But Imperfectly-Stabilized Nominal GDP Growth in the Great Recession than in the Great Depression

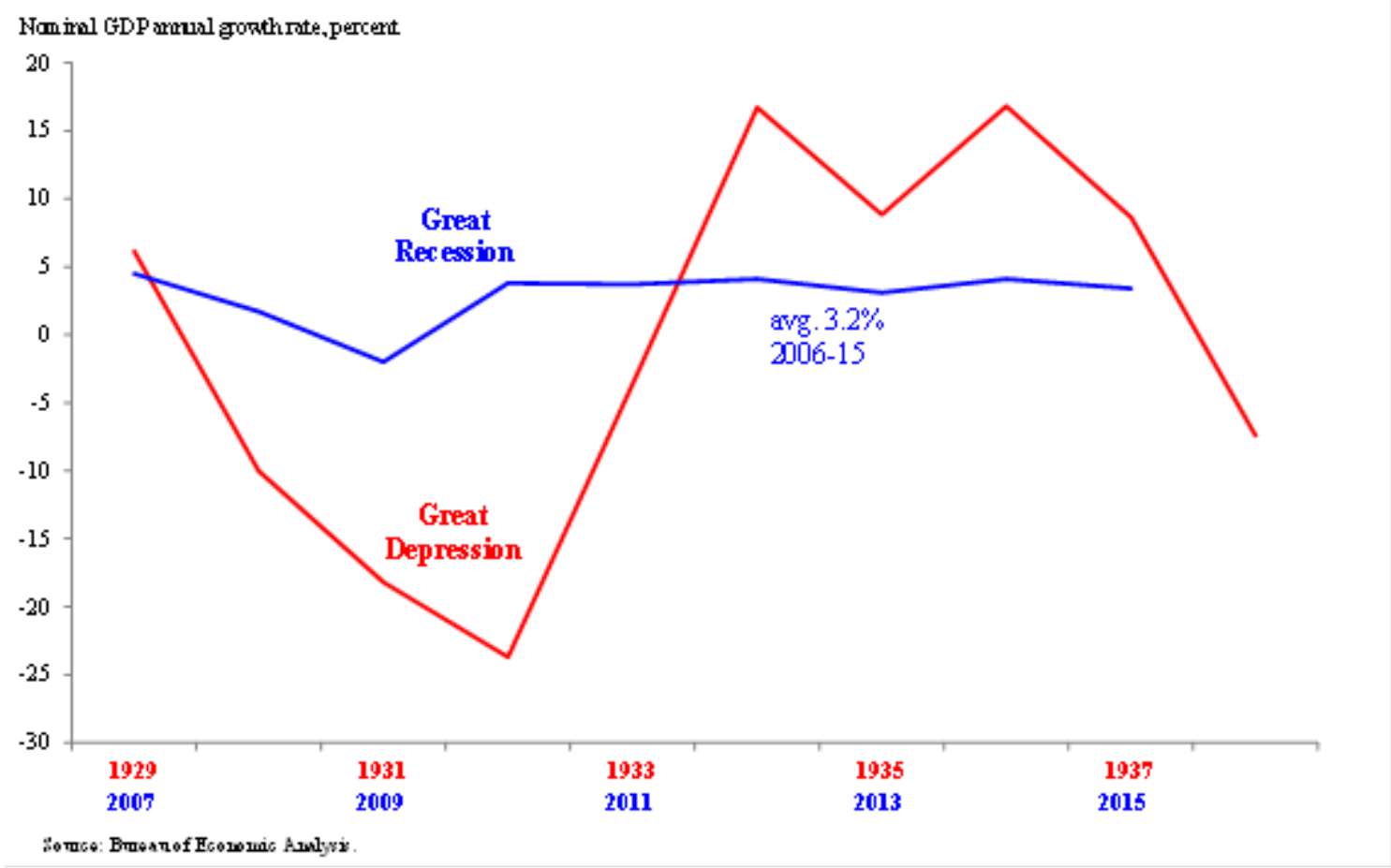

Figure 7: M2 Declined in the Great Depression, But, Except in 2010, Rose Solidly in the Great Recession

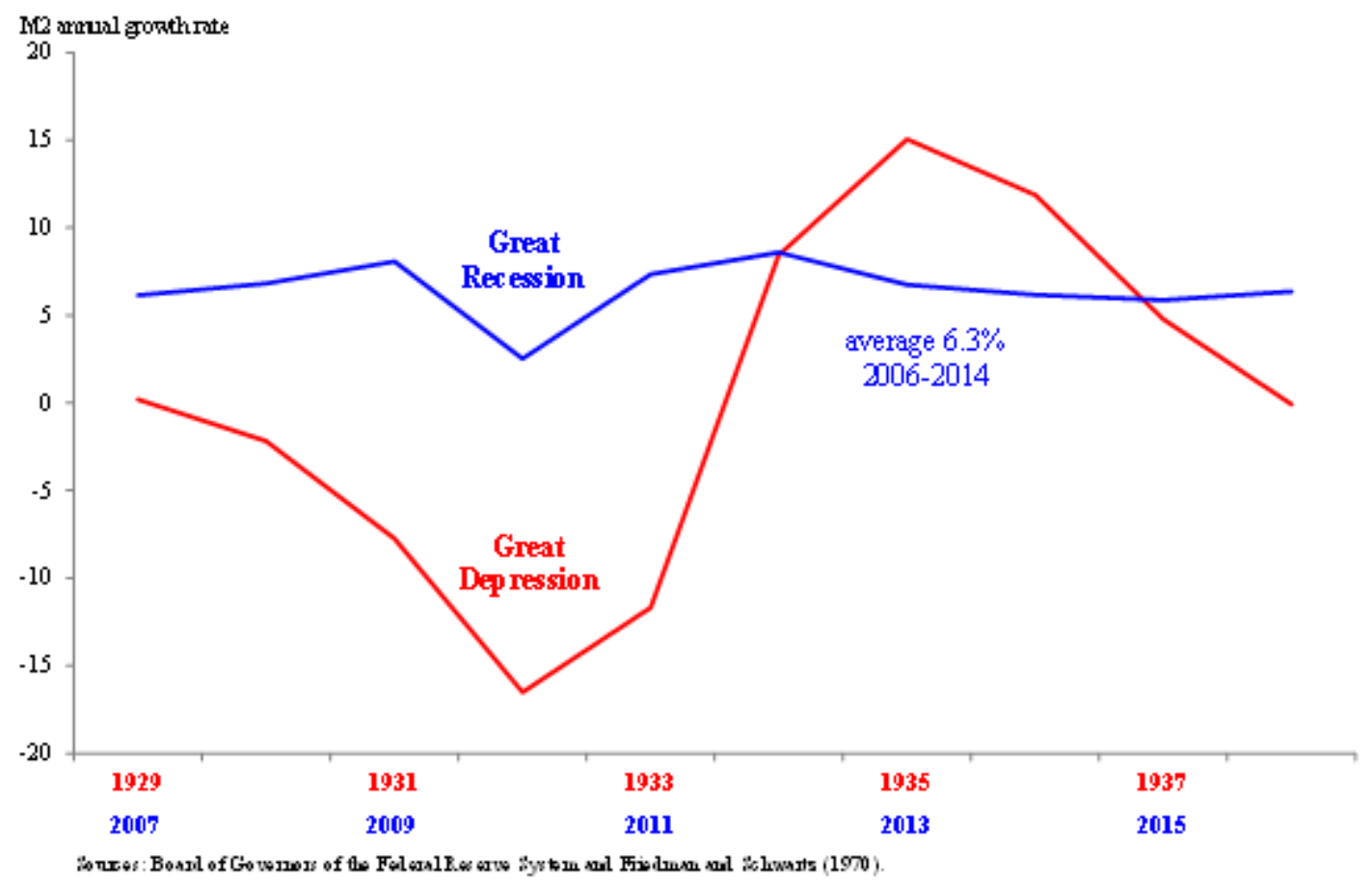


Our analytical framework illustrates both differences and similarities between the Great Depression and the Great Recession, as highlighted in Figures 2 and 3. Financial crises understandably increase risk premia, affecting money demand. Measured by the spread between the yields on Baa-rated corporate bonds and 10-year Treasuries (Figure 2), risk premia peaked in 1932 and 2009 for the Great Depression and Great Recession, respectively. Perhaps surprisingly, measured risk premia retreated more rapidly during the Depression: 1929's premia was rejoined by 1935, while year-end 2013 risk premia remain above pre-crisis lows, albeit near 2002-2003 levels. Our empirical results suggest an important explanatory role of this premia for the behavior of velocity before and after the crises (Figure 3). In the Depression, velocity rapidly regained its earlier level following stabilization of the banking system; in the Great Recession, it has not. Both crises were followed by extensive bank regulatory reform—judging the relative impacts of the reforms on velocity is difficult. In Figure 3, for example, we show for the Great Recession both the actual path of M2 velocity and a counterfactual path based on an estimate of the Dodd-Frank Act's pressure to shift credit provision back into the formal banking sector from the shadow banking system (Duca, 2014). Because the latter derives much of its funding from M2 components, these provisions tended to lower M2 velocity, consistent with the view emphasized by Bordo and Jonung $(1987,1990,2004)$ that major changes in financial institutions critically affect money demand. As a result, there are difficulties with disentangling financial reform from risk premia effects in the current environment. Estimation of these effects is discussed further below.

In both periods, an initial fall in M2 velocity exceeded amounts implied by historical changes in income and interest rates. Later, in the mid-1930s, velocity rose and stabilized as uncertainty ebbed, as Friedman and Schwartz (1963) note. Velocity fell late in World War II 
likely due, in part, to fear of a post-war collapse similar to that after World War I and to forced saving from goods-rationing (Rockoff, 1981). More recently, the higher uncertainty that accompanied the onset of the Great Recession induced a rise in money demand and drop in velocity.

\section{Previous Studies of Long-Run Money and Financial Crises}

Studies of the demand for money over long periods of time must confront shifts in money demand. Traditionally, studies regarding the demand for broad money in the United States asserted or assumed that the effects of increasing financial sophistication and innovation are well-captured either within either the definition of a broad money aggregate (as reconstructed for earlier periods using contemporary definitions) or the path of nominal (or real) income. Although the importance of financial innovation was acknowledged, its effects often were addressed only via exogenous dummy variables. "Breakdowns" in empirical money demand relationships, most often, were traced to the inadequacy of such variables.

The literature on the role of financial innovation is vast. Well before the recent financial crisis, Ford and Mullineux (1996) ably summarized the issues both for money demand and financial market stability:

"The recent decades, and more particularly the last two, have seen the most substantial evolution, maybe we should say revolution, in the financial and monetary sectors of the developed nations of the world. In the financial sector in the broad sense, many new types of financial claims (both assets and liabilities) have emerged. Some of these claims have appeared in what we might strictly call the banking sector. [Others] have arisen because of attempts to insure against the uncertainty in financial markets, which has become an increasingly important feature of the global economic scene. The volatility that has occurred in those markets probably owes a significant part of its existence to the integration, and liberalization, of markets that have been dominant phenomena in many western economics.” 
A decade later, Federal Reserve Chairman Ben Bernanke (2006) echoed the financial innovation theme at the ECB's fourth central banking conference ${ }^{8}$ :

Why have monetary aggregates not been more influential in U.S. monetary policymaking, despite the strong theoretical presumption that money growth should be linked to growth in nominal aggregates and to inflation? In practice, the difficulty has been that, in the United States, deregulation, financial innovation, and other factors have led to recurrent instability in the relationships between various monetary aggregates and other nominal variables.

...the rapid pace of financial innovation in the United States has been an important reason for the instability of the relationships between monetary aggregates and other macroeconomic variables. In response to regulatory changes and technological progress, U.S. banks have created new kinds of accounts and added features to existing accounts. More broadly, payments technologies and practices have changed substantially over the past few decades, and innovations (such as Internet banking) continue. As a result, patterns of usage of different types of transactions accounts have at times shifted rapidly and unpredictably.

...the empirical relationship between money growth and variables such as inflation and nominal output growth has continued to be unstable at times.

Historically, the economic function of financial innovation has been to increase the liquidity of otherwise less-liquid assets, i.e., to reduce the transaction costs of converting assets that are not medium-of-exchange into medium-of-exchange (e.g., Hasbrouck, 2009). Some such innovation has occurred with the regulated, chartered banks. But innovation also has occurred elsewhere, most notably in the mutual fund industry, where the costs of transferring assets into mutual fund accounts have plunged, prompting greater stock ownership rates among middle-income families.

We focus this study on the broad monetary aggregate, M2. Previous long-run money demand studies, focused on the transactions motive for money demand, generally have used M1. ${ }^{9}$ Friedman and Schwartz (1970), however, argue that data availability supports only a broad money aggregate for long-run studies. They note that prior to the mid-1930s there was little

\footnotetext{
${ }^{8}$ Bernanke (2006) notes that the Federal Reserve Board's P* model (Hallman, Porter and Small, 1991) was developed to predict long-run inflation using long-run potential output and velocity. This model's performance can be improved by accounting for financial innovation, specifically, the decreasing transaction cost and increasing use of bond mutual funds; see Brecsi and Duca (1994). Judson, Schlusche, and Wong (2014) update the 1988 Federal Reserve Board M2 demand model (Moore, Porter and Small, 1990) and conclude that the model works well, with minor adjustments, from 1959-2011, when the period during which it performs poorly (1990-1993) is omitted.

${ }^{9}$ Although there are a number of previous studies of long-run U.S. money demand, most such studies have used M1, not a broad monetary aggregate, e.g., Wang (2011), Lucas (1988), Stock and Watson (1993), and Ball (2001).
} 
economic difference between banks' different types of deposits because banks often waived early withdrawal penalties on time deposits. (The difference between M1 and M2 became important during the 1930s when regulatory changes introduced statutory reserve requirements by type of deposit and prohibited the payment of interest on demand deposits.) They study the behavior of a broad definition of money (currency plus all deposits held by the public at commercial banks) from the mid-1870s to the mid-1970s. ${ }^{10}$ Two forces, prominent in their study, also feature in ours-increasing financial sophistication and increasing per capita real incomethe former tending to increase velocity and the latter to reduce it. Bordo and Jonung (1987, 1990, 2004) examine the period 1880 to 2000, and Bordo, Jonung, and Siklos (1997) examine the period from the late 1800s to the late 1900s. Our research echoes theirs by emphasizing the roles of increasing financial sophistication and decreasing financial transaction costs.

Large shocks to the underlying data generating process are the bane of all long-term empirical analyses. Financial crises are the major focus of our analysis. Wars, however, are nuisance parameters that cannot be ignored. During our sample period, only World War II appears to have affected money demand by distorting consumption, saving, and asset holding. Velocity rose rapidly early in the war, thereafter declining steadily but slowly during $1944-46 .{ }^{11}$ These movements reflected very low short-term rates and the Federal Reserve "pegging" longterm bond yields. ${ }^{12}{ }^{13}$ How to model the effects of WWII? For example, including defense

\footnotetext{
${ }^{10}$ Friedman and Schwartz (1982) note that the deposit figures for 1867 through 1946 are theirs, and for currency through 1942. Thereafter they use Federal Reserve figures. Subsequent changes in the definition of M2 make untenable using exactly the same figures. Our figures for 1946 to 1958 are from Rasche (1992); earlier data are from Friedman and Schwartz. See Anderson (2003). We avoid Friedman and Schwartz's difficulties regarding income and prices by using annual data and currently published Department of Commerce figures beginning in 1929. Also, we use standard time-series methods, not the "reference phase" statistical framework of Friedman and Schwartz.

${ }^{11}$ In contrast, velocity fell during most of WW I. See Friedman and Schwartz (1982), chapter 5.

${ }^{12}$ Friedman and Schwartz (1982, pp. 101-2) argue that wartime real output is overstated because "price control meant that price increases took indirect and concealed forms not recorded in the indexes" and that "the large rise in price indexes when price control was repealed in 1946 consisted largely of an unveiling of the earlier concealed increase." They argue that "true" average prices during the war were unobservable because some transactions
} 
spending or a dummy for the onset and lifting of price controls is unlikely to fully reflect the interaction of these effects and the expectations impacts arising from them. Also, including direct measures of defense spending raises simultaneity issues. Accordingly, we add separate yearly dummies for 1941-46 to control for the time-varying impact of WWII and to prevent it from biasing coefficient estimates. ${ }^{14}$

\section{The Empirical Model: Specification}

The canonical model of the demand for broad, liquid money, as developed during the 1980s, represented velocity as a function of its opportunity cost, often measured as the difference between money’s own rate of return and a short-term default risk-free market yield (e.g., 3- or 6month Treasury bill yield). Among other things, these models hinged on conclusions that (i) the income elasticity of broad money demand was unity, and (ii) the structure of risk premia (across risky assets) was (largely) temporally stable (that is, not highly time-dependent), and (iii) the effects of financial innovations were encapsulated within the broad money aggregate. ${ }^{15}$

occurred above controlled prices and others were black market transactions. As noted above, Friedman and Schwartz (1982, chapter 4) develop a method of adjustment that replaces observed prices during 1943-46, and hence, changes measured real output. They note that, because of the "different economic circumstances" during World Wars I and II, they often present separate results calculated with and without the war years. They also make data adjustments for the price control period 1971 Q3 -1973 Q3.

${ }^{13}$ A reasonable person might disagree, arguing that the measured prices are accurate but, due to rationing, the measured prices were not market-clearing and the 1946 increase reflected only an adjustment to those prices. As an adjustment to published data, they argue that measured nominal income likely was less distorted by illegal activity than measured prices, and use the method of interpolation-by-related-series (interpolating the price index by net national product) to construct replacement values for the price index during 1943-46. Although elegant, we do not pursue the Friedman and Schwartz adjustment. Friedman and Schwartz (1982), pp. 104-105, make a similar adjustment for the 1971-74 price controls. For the reasons stated above, we do not make such an adjustment.

${ }^{14}$ The effect of the dummy variables, of course, is to set the residuals for these periods to zero, thereby removing their influence in estimating the equation's coefficients.

${ }^{15}$ This practice, at times, resulted in large numbers of "monetary aggregates," M1, M2, M3, M4 M5, M6, etc. Some financial innovation is not subsumed in the aggregate. We include these explicitly in the model, below. 
Combined, these conditions suggested that both the opportunity cost of M2 and its velocity were mean-reverting. ${ }^{16}$ The long-run equilibrium for such a model might be written as

$$
\ln V 2^{*}-\alpha_{0}-\alpha_{1} O C^{*}=0
$$

where $V_{t-1}^{*}$,denotes the unobserved, latent equilibrium velocity and $O C^{*}$ denotes the latent equilibrium opportunity cost (that is, a spread between the weighted-average own rate on M2 and a short-term, default risk-free money market instrument). In long-run equilibrium, $V 2^{*}=V 2_{t}$ and $O C^{*}=O C_{t}$ for all $t$. An estimable model might be written as

$$
\ln V 2_{t}=\alpha_{0}+\alpha_{1} \ln V 2^{*}+\alpha_{3}\left(O C_{t}-O C^{*}\right)+\varepsilon_{t}
$$

with short-run deviations from the long-run equilibrium as:

$$
\Delta \ln V 2_{t}=\beta_{0}+\beta_{1}\left(\ln V 2_{t-1}-\ln V 2_{t-1}^{*}\right)+\beta_{2} O C_{t-1}+\beta_{3} \Delta \ln V 2_{t-1}+\varepsilon_{t}
$$

The omission from the model of assets other than short-term Treasury securities asserts that portfolio substitution, as it affects M2 holdings, is between liquid broad money (M2) and shortterm government debt. Such a specification likely was defensible until the late 1980s; see Friedman and Schwartz (1982), Lucas (1988), Meltzer (1998), Moore, Porter and Small (1990), Hallman, Porter, and Small (1991), Small and Porter (1989), Rasche (1989, 1992), and more recently Judson, et al. (2014). The accompanying short-run dynamic model, aside from dummy variables for special events, then necessarily asserts that changes in V2 reflected changes in money’s opportunity cost.

Empirical difficulties with this framework became apparent in the early 1990s, when an episode of unexpectedly high velocity became known as the period of "missing” M2. ${ }^{17}$ Almost

\footnotetext{
${ }^{16}$ This argument is not wholly original. See Moore, Porter and Small (1990) and Hallman, Porter and Small (1991).

${ }^{17}$ See for example Carlson, Hoffman, Keen, and Rasche (2000).
} 
immediately, suspicion fell on two omitted variables: (i) financial innovation, and (ii) sharp swings in risk premia. Although broad M2 had successfully incorporated within itself many innovations that affected depository institution liabilities, financial innovation now was reducing the cost of asset exchanges between M2 and liquid money market instruments, including raw bonds and equities, and bond and equity mutual funds. ${ }^{18}$ Initially, this effect revealed itself empirically as time variation in the elasticity of substitution between M2 and alternative assets (Duca, 2000), and was most pronounced for small-denomination time deposits (Carlson, et al., 2000). ${ }^{19}$ Experiments to "repair" the problem included narrowing the definition of M2 to exclude small-denomination time deposits, so-called "M2 minus" (e.g., Carlson, et al., 2000) and broadening the definition to include additional liquid assets, such as bond funds, so-called M2 plus” (Besci and Duca, 1994).

Clever ad hoc efforts to repair M2 demand models by redefining M2 were ultimately unsuccessful. A more satisfactory approach is to explicitly model the changing margin of substitution between M2 and alternatives. The increased holding by households of mutual funds is the most important—and most neglected—financial innovation of recent decades. Mutual funds are the main vehicle for most households to feasibly own a diversified portfolio of stock and bonds. Moreover, mutual fund transaction costs are proportional, not fixed—precisely the type of cost that Brunner and Meltzer (1967) had noted was most likely to affect portfolio behavior and, hence, money velocity. Duca (2000) was among the first to include such costs in an empirical model, arguing that omitting the switching costs between M2 and its alternatives induced an omitted variable bias in M2 demand models,

\footnotetext{
${ }^{18}$ We are not the first to mention financial innovation as a culprit. As noted above, Friedman and Schwartz (1982) mention it throughout their analysis, often combined with the hope that omitting measures of innovation from their equations does little harm. Bordo and Jonung $(1987,2004)$ stress financial sophistication, which is closely related.

${ }^{19}$ The modelling challenge presented by such shifts is not be underestimated. Judson et al (2014), for example, simply omit 1990-1993 from their regressions because the regressions do not fit the data.
} 


$$
\ln V 2^{*}-\alpha_{0}-\alpha_{1} O C^{*}-\alpha_{2} \ln (\mathrm{load})=0
$$

where load is the average load (that is, front-end fee) charged to customers when they transfer assets into bond or stock mutual funds.

Explicit inter-asset transaction costs were not the only omitted variable afflicting money demand: elementary portfolio theory also counsels that risk premia matter. In the decades prior to the 1990s, risk premia moved within a small range; thereafter, relative to earlier decades, the swings became increasingly sharp. ${ }^{20}$ By reducing the predictability of asset prices, these swings have notably altered investors' perceptions of the liquidity of nonmonetary assets, including stocks and bonds. The importance of time-variation in the risk premia's variance has long been noted by monetary theorists, perhaps most prominently Tobin (1958), who emphasized the speculative demand for money, and Friedman and Schwartz (1963, chapters 11 and 12), who noted the link between higher corporate bond risk premia and the fall in money velocity during the Great Depression. Empirical attempts to model such effects by including variables such as changes in stock returns met with mixed success (e.g., Hamburger, 1966, 1977; Carlson and Schwartz, 1999), most likely because the empirical relationship between money demand and risk premia was neither sufficiently stable nor strong (e.g., Duca, 2000).

What has not been recognized, prior to this study, is that the omitted variable problem hinges on the interaction between financial innovation and time-varying risk premia. Financial innovations that reduce asset trading costs lower both the cost of diversification and that of hedging risk. As predicted in Tobin’s (1958) general equilibrium model, combined, these have sharply altered underlying portfolio behavior with respect to how risk premia affect money

\footnotetext{
${ }^{20}$ Most analysts seek to measure risk premia in equity markets. Unfortunately, the lack of an effective risk-free rate makes difficult measurement before 1925 (see Goetzmann and Ibbotson, 2008). In more recent data, survivorship bias complicates precise measurement (see Brown, Goetzmann, and Ross, 1995).
} 
demand: lower transaction costs reduce the costs incurred by investors as they response to shifts in perceived risk. Moreover, smaller transaction costs narrow the "no-action zone" in inventory models. ${ }^{21}$ Further, lower transaction costs raise the optimal size of each portfolio rebalancing, for a given size change in relative returns or risk. Among such events are "flight-to-quality" dynamics.

Liu (2004) constructs a model in which fixed and proportional asset transfer costs affect the optimal consumption and portfolio behavior of households with constant relative risk aversion, and concludes that portfolio shares reflect differentials in pecuniary yields between safe and risky assets (e.g., the Treasury yield premium or a corporate-Treasury bond yield differential) scaled by proportional asset transfer costs in levels. More specifically, he finds that portfolio shares approximately reflect negative linear tradeoffs between expected return differentials and proportional asset transfer costs. In log specifications, this implies that the logs of a risk premium and an asset transfer cost series enter as separate factors determining long-run equilibrium velocity:

$$
\ln V 2_{t}^{*}=\alpha_{0}+\alpha_{1} \mathrm{OC}_{\mathrm{t}}+\alpha_{2} \ln (\mathrm{load})+\alpha_{3} \ln \left(\text { Baa } 10 \mathrm{TR}_{\mathrm{t}}\right)+\varepsilon_{t}
$$

where the (log of) the risk premium, denoted Baa10TR, is measured as the difference between the Moody’s Baa yield and the 10-year Treasury constant maturity yield.

In our empirical work, we cannot reject the hypothesis that the variables V2, load, Baa10TR, and OC are usefully modeled as I(1), that is, that the first-differences are covariance

\footnotetext{
${ }^{21}$ Transaction costs create a no-action zone in which it is optimal not to trade until portfolio misalignment is sufficiently large to warrant incurring the transaction costs. The width of this zone is inversely proportional to the size of the transaction cost. As proportional transfer costs (such as mutual fund loads) decline, the zone of portfolio inaction narrows (e.g., Davis and Norman, 1990; Liu and Loewenstein, 2002; Zakamouline, 2002). The models imply that a decline in transaction costs (e.g, mutual fund loads) increases the likelihood that households will realign portfolios in response to a given change in the relative risk or rates of return on money versus other assets.
} 
stationary. Further, we cannot reject the statistical and economic significance of both variables; hence, omitting either variable induces a composite error and inconsistent parameter estimates.

Empirically, the issue is manifest in the correlation between the size of the Baa-Treasury yield spread and the levels of corporate equity and bond prices. During flights to quality, the spread widens as stock and bond prices decrease and Treasury prices rise. As a result, currentperiod yields on corporate assets fall and yields on Treasuries rise. In future periods, yields on corporate assets will increase relative to the current period and yields on Treasuries will fall. In such models, increases in opportunity costs are asserted to reduce the quantity demanded and increase velocity_-but this need not happen after flights to quality because default and liquidity risk premia are changing. Although not perfect, including Baa10TR is a step towards preventing flight-to-quality effects from contaminating the effect of the opportunity cost.

We complete the model by augmenting eq. (5) with a dynamic short-run equation, in the form of an error-correction model:

$$
\ln V 2_{t}^{*}=\alpha_{0}+\alpha_{1} \ln \left(\operatorname{load}_{t}\right)+\alpha_{2} \ln \left(\text { Baa10TR }_{t}\right)+\alpha_{3} O C_{t}+\varepsilon_{t}
$$

$$
\Delta \ln V 2_{t}=\beta_{0}+\beta_{1}\left(V 2_{t-1}-V 2_{t-1}^{*}\right)+\beta_{2} \Delta \ln \left(\operatorname{load}_{t-1}\right)+\beta_{3} \Delta \ln \left(\text { Baa10TR }_{t-1}\right)+\beta_{4} \Delta O C_{t-1}+\beta_{5} D_{t}+v_{t}
$$

where $D_{t}$ denotes a vector of dummies used as short-run controls for events not otherwise captured.

\section{The Empirical Model: Data}

This section explores measures of two innovations in our study: the declining costs of exchanging M2-type assets for bond and stock mutual funds, and the increasing volatility of the risk premium in U.S. financial markets. We also discuss the conventional measure of M2's opportunity cost. 


\section{Mutual Fund Loads}

Exchanges into bond and equity mutual funds are the most important substitution margin for the households that hold M2-type assets. ${ }^{22} \mathrm{~A}$ decrease in mutual fund transaction costs both tends to increase bond and stock fund ownership rates among households and to ease portfolio substitution between M2 and those funds, altering the measured interest elasticity of money demand. Heaton and Lucas (2000) demonstrated that high asset transfer costs for households that exhibit habit formation in consumption can lead to low stock ownership rates. Duca (2005, 2006), using data from the Federal Reserve's Survey of Consumer Finances, found a significant

Figure 8: Equity Fund Loads Fall and Stock Ownership Rates Rise

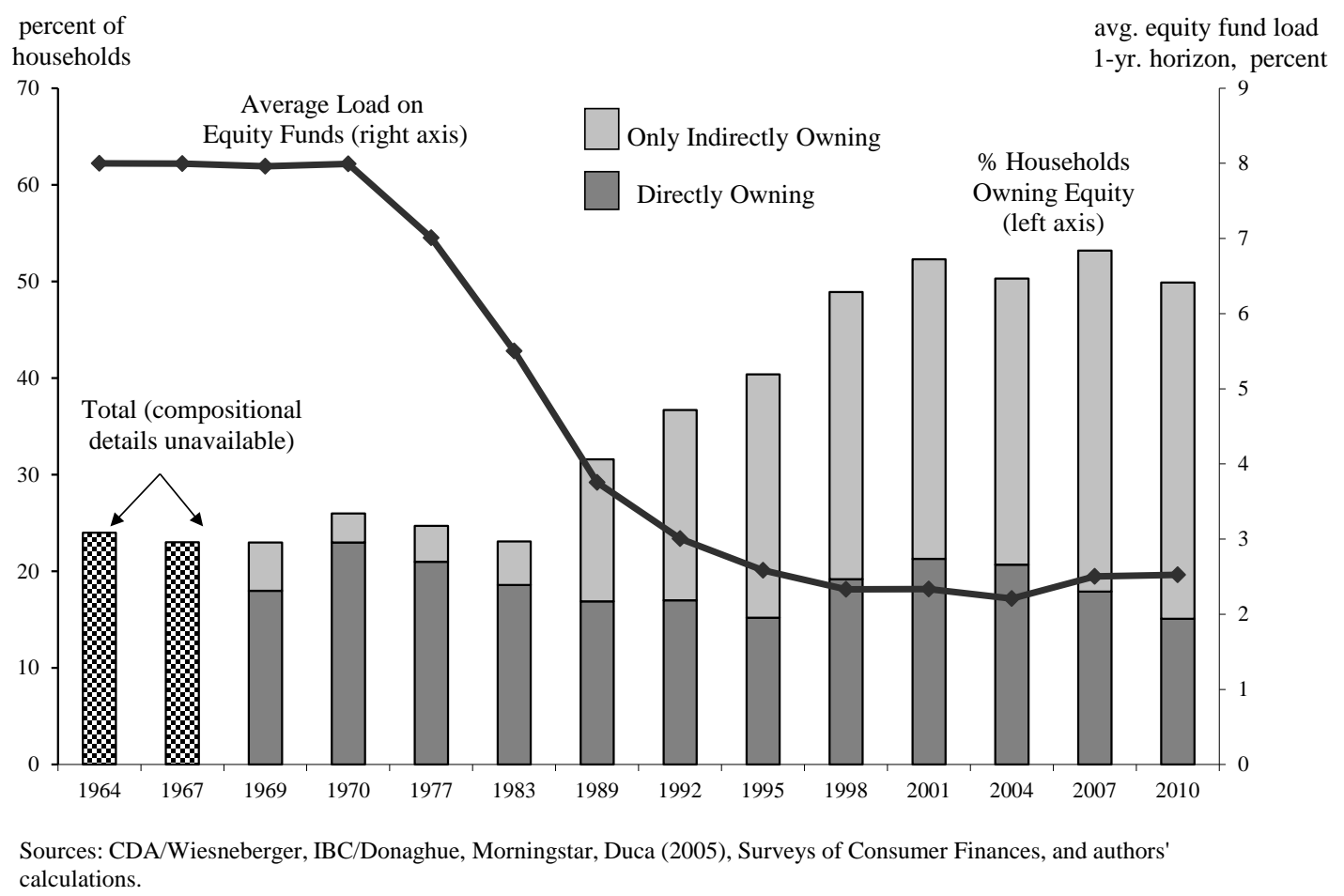

\footnotetext{
${ }^{22}$ Here, M2-type assets include currency but are overwhelmingly the deposit products offered by depository financial institutions in minimum balances less than $\$ 100,000$. Businesses also hold such products but are more likely to offer low transaction cost alternatives with near-market returns, including sweeping deposits into Treasury bills or institutional-type money market mutual funds (e.g., Fleissig and Jones, 2015). Unfortunately, little data is available regarding household versus business ownership of deposits at depository financial institutions.
} 
negative correlation (of about -1 ) between average equity fund transaction costs (loads) and stock ownership, for both direct and indirect (via mutual funds) stock ownership (Figure 8). He further found that higher average equity participation arose largely from greater mutual fund ownership among middle-income families; in turn, these families M2-type assets had grown more slowly relative to high-income families.

In this study, we update and extend data on mutual fund costs used in Anderson and Duca (2014) and Duca (2000). In those studies of post-war quarterly M2 demand, transaction costs measured by bond fund loads outperformed those based on stock fund loads. This study, however, measures transaction costs using stock fund, rather than bond fund, loads, for two reasons. First, our purpose here is to examine a longer span of time: in contrast to stock funds, data on bond funds do not cover the 1920s and 1930s and provide limited evidence on the 1940s. ${ }^{23}$ Second, as discussed below, we use a proxy for risk premia — the spread between yields on Baa-rate corporate and 10-year Treasury bonds-which reflects the riskiness of both stocks and private bonds.

As in Duca (2005), we measure stock fund loads as the fee incurred when a fund is purchased (front-end load) or incurred when a fund is sold after less than one year of ownership (back-end fee), both expressed as a proportion of assets (Figure 9). ${ }^{24}$ While this series cannot capture all aspects of asset transfers, for two reasons it likely well-proxies time series movements in asset transfer costs. First, empirical evidence suggests that technological change (that is, falling information technology costs), rather than economies of scale, has been the primary driver of falling mutual fund costs. Specifically, the difference between the limited (1968-1998)

\footnotetext{
${ }^{23}$ Only one bond fund existed before 1950 and it started in 1940, whereas a few stock mutual funds existed in the 1930s, with two prominent ones starting in the 1920s.

${ }^{24}$ We also tested loads using a longer 5 year horizon and/or adjusted for expense ratios (see Duca, 2005). These other variants were significant but did not perform as well as the series used here which corresponds more closely with tracking asset transfer costs.
} 
Figure 9: Stock Mutual Fund Loads Shift in the Last Several Decades

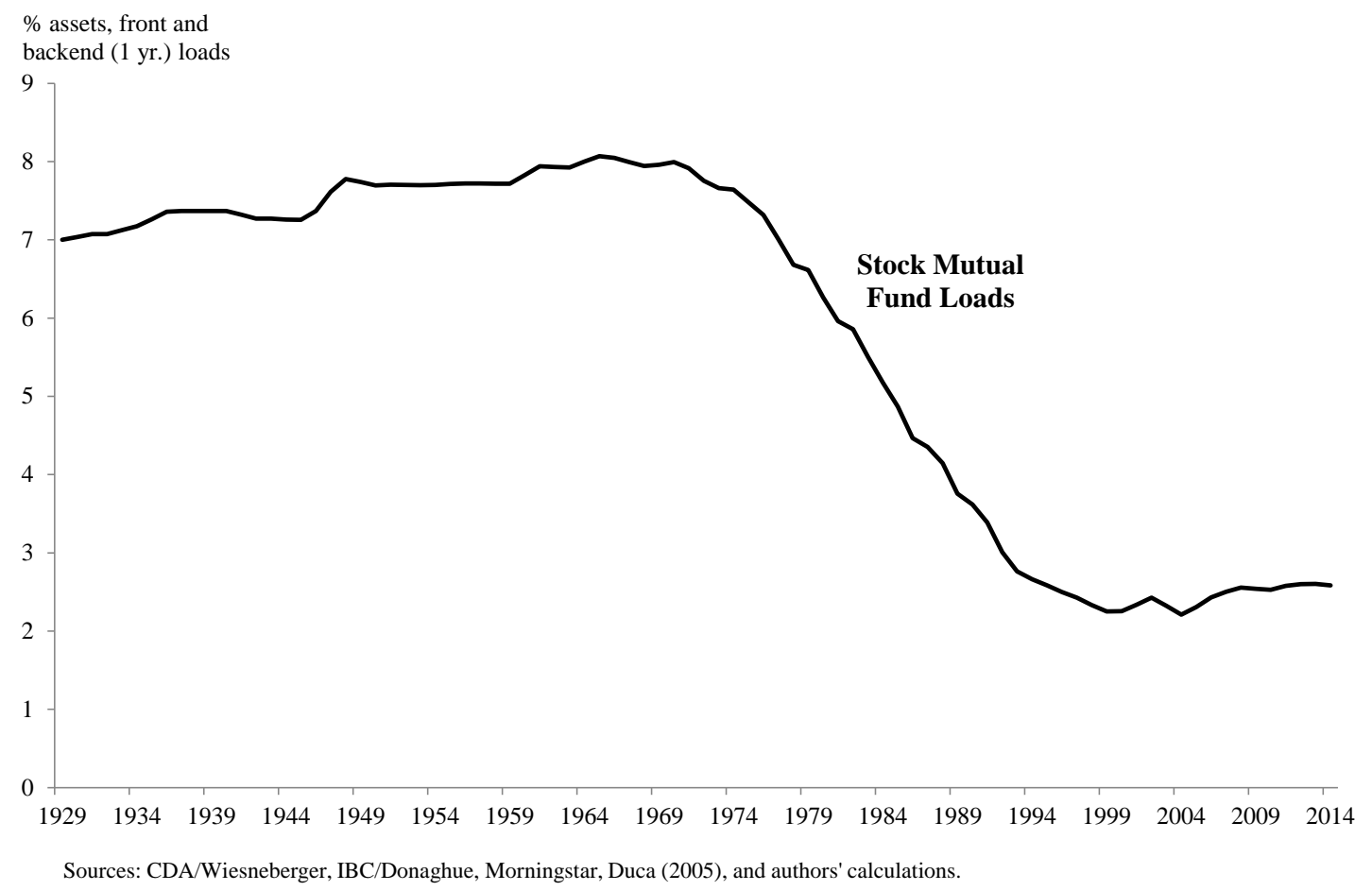

available data on banking sector productivity (the closest time-series proxy for financial sector productivity) and data on mutual funds costs are stationary, and weak exogeneity tests suggest that bank productivity Granger-causes stock mutual fund loads in a long-run sense (Duca, 2005). Second, empirical evidence suggests that mutual fund costs notably influence the composition of household portfolios. Specifically, stock mutual fund costs are cointegrated with-and are highly and negatively correlated with—stock ownership rates, with weak exogeneity tests indicating causality running from long-run trends in mutual fund loads to equity participation rates (Duca, 2013).

At the aggregate time series level, several empirical patterns imply that mutual fund loads are a driver of M2 velocity. Duca (2005) found that stock mutual fund loads mainly reflect evolving financial technology. In vector error-correction models, loads were weakly exogenous with respect to the use of mutual funds to own stock but not vice versa, while loads were not 
weakly exogenous to financial sector productivity, but the converse was true. Granger and Lin (1995) would view such results as evidence that mutual fund use is caused, in a long-run sense, by loads, which are caused by financial technology. Similarly, below we conclude that stock mutual fund loads are weakly exogenous to M2 velocity, while velocity is not weakly exogenous to stock fund loads. These findings imply that trends in loads lead those in velocity, consistent with the view that asset transfer costs Granger cause money demand in a long-run sense.

\section{Risk Premia and Stock Returns}

Households' perceived risk premia is an important variable in our analysis. We measure the risk premia as the spread between yields on Baa corporate bonds and the 10-year Treasury constant-maturity yield. This measure includes compensation to investors for the higher default and liquidity risk on the Baa bond (the lowest investment grade corporate bond). Evidence suggests that, via arbitrage, it also measures risk in stock prices: The portfolio share of stocks for the household sector shows much more variation than that of bonds (Federal Reserve Financial Accounts), implying that both include a common risk premia. Further, an equity risk premium measured as the gap between the earnings-price ratio for nonfinancial corporate stocks and a real ex post bond yield is more stable when measured using the Baa corporate yield, rather than the 10-year Treasury yield (chart available upon request from the authors).

We construct our measure using the Moody’s Baa yield from the 1920s to 2014. For Treasury yields, from April 1954-2014 we use the constant maturity 10-year Treasury yield. For 1941-54, we use Federal Reserve data on the average yield on long-term U.S. Government securities, and for 1926-41 we use a separate U.S. government bond yield series. The series are spliced by matching the levels during overlapping periods with small additive adjustments. The 
series are compared in Figure 2 (above) for the periods of the Great Depression and the Great Recession, while entire the time series is plotted in Figure 10 below.

Figure 10: The Spread Between Baa Corporate and 10 Yr. Treasury Yields Trends, Especially When Scaled by Mutual Fund Transfer Costs

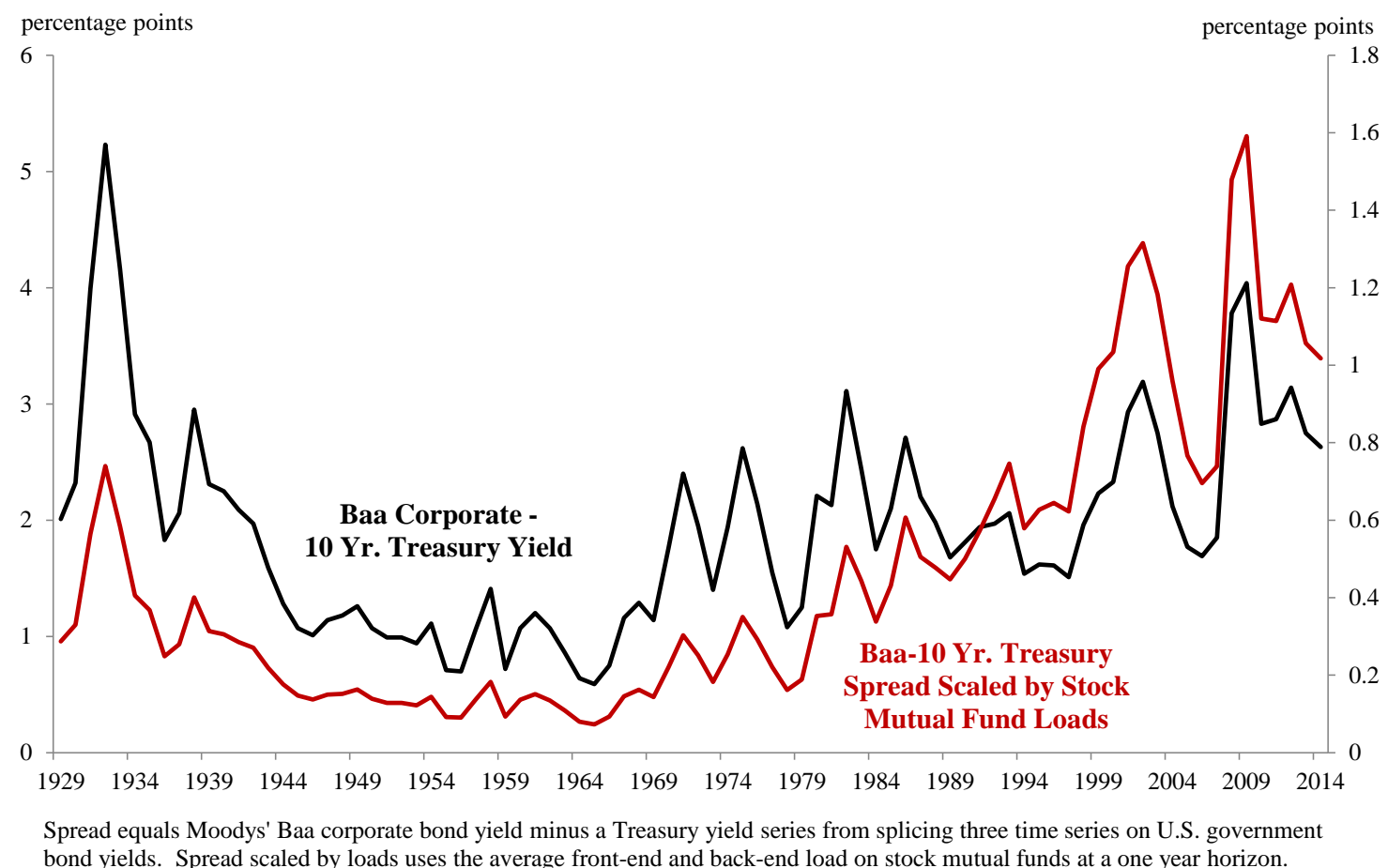

ADF tests suggest that shocks to our risk premia measure are persistent, that is, the hypothesis of I(1) “permanent” shocks cannot be rejected. Persistence in the risk premia measure is even more pronounced when scaled by stock fund loads (Figure 10), which according to Liu's (2004) model, should be correlated with portfolio behavior.

In addition to the measured risk premia, our empirical baseline model includes stock loads in the cointegrating vector and the short-run dynamic equations; in the latter, it seeks to capture the time-varying sensitivity of M2's velocity to stock returns and risk premia. Our baseline model also includes a variable measuring the opportunity cost of M2 relative to stocks, OCST, equal to the difference between ex post returns on all U.S. stocks (dividends and capital gains, as in Shiller, 2014) minus M2's measured own rate of return. Empirically, we cannot 
reject that OCST is stationary. We include it in the short-run (dynamic adjustment) portion of the error-correction model in levels, with a one-period lag (several annual values are negative; see Figure 11).

Figure 11: M2 Opportunity Costs Relative to T-Bill Rates Have Trends, But Relative to Stock Returns Are Volatile

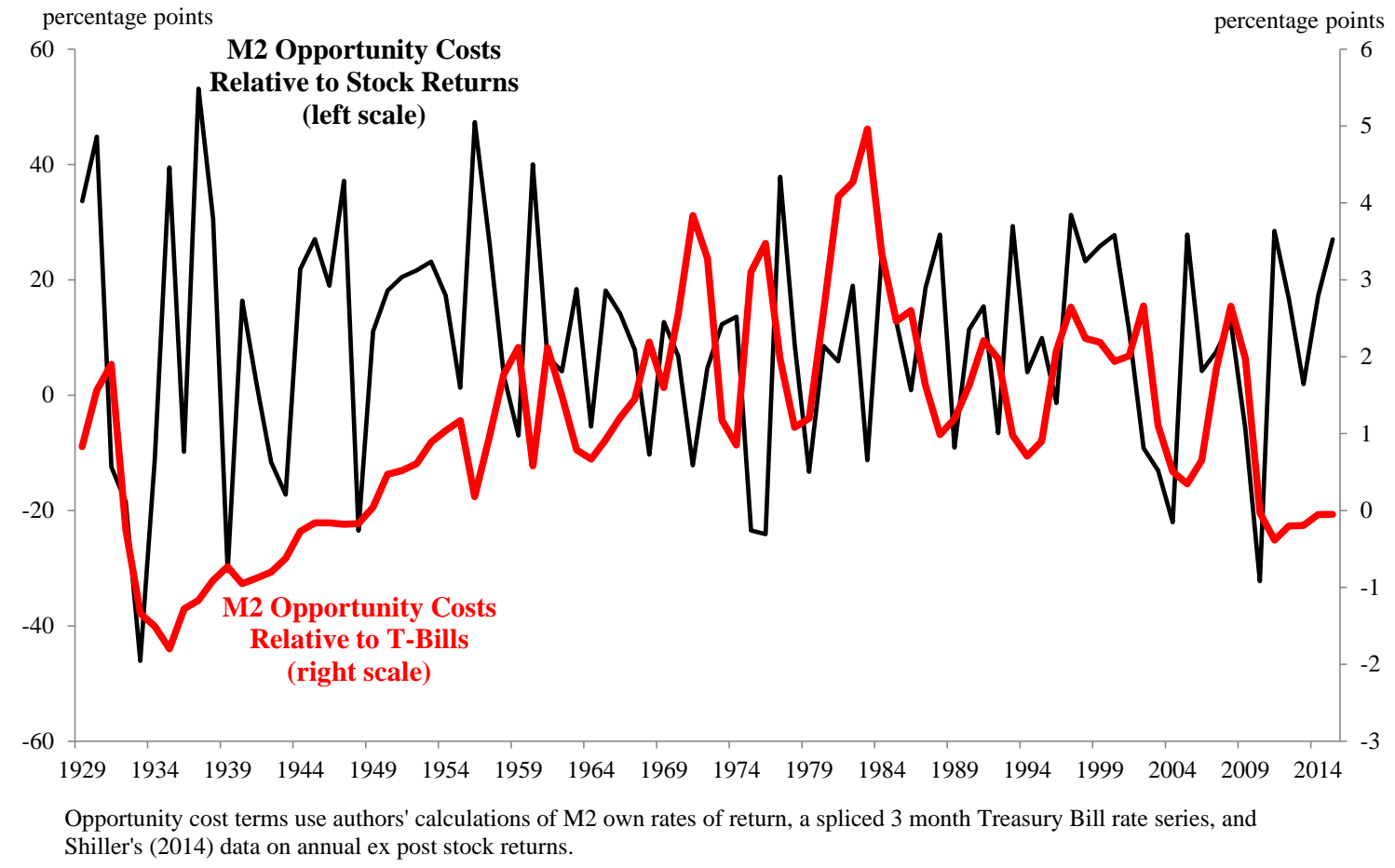

Conventional Opportunity Cost of Money

Our baseline specification includes a conventional measure of the opportunity cost of M2: the difference between the yield on a short-term Treasury security minus the weightedaverage measured rate of return on M2 balances. The former is measured for 1934-2014 as the bond-equivalent yield on 3-month Treasury bills and for 1926-33 as the average of the 3-month and 6-month Treasury bill rate. The average pecuniary yield on M2 for 1958-2014 is annual averages of Federal Reserve Board estimates. Prior to 1958, we calculate the average rate on demand and time deposits from OCC reports on active banks, and weight these rates by demand 
and time deposit shares of M2, taking into account currency outstanding. ${ }^{25}$ Because the resulting annual opportunity cost series (OC, Figure 11) has a unit root and a few negative values, its level enters the model by being a determinant of long-run velocity, thus affecting the change in velocity via the error-correction term and lagged first-difference terms.

\section{Other Data}

Our model uses annual observations 1927-2014. Nominal GDP for 1927-1928 is from Balke and Gordon (1986), thereafter from the U.S. Department of Commerce. Money stock is broad money (M2), for 1927-1945 from Friedman and Schwartz (1970), for 1946-1958 from Rasche (1992), and thereafter from the Federal Reserve Board. ${ }^{26}$ Interest rates are annualized Treasury constant-maturity rates on a bond-equivalent basis. The Baa rate is the average yield to maturity on corporate bonds rated Baa by Moody’s Investor Services. We measure stock fund loads as in Duca (2005), equal to the proportional fee (percent of assets) levied when a mutual fund is purchased or the fee levied for withdrawing funds within a year of purchase (Figure 9). ${ }^{27}$

\section{The Empirical Model: Estimates}

Recall our baseline empirical framework is laid out in equations (6a, 6b):

$$
\ln V 2_{t}^{*}=\alpha_{0}+\alpha_{1} \ln \left(\operatorname{load}_{t}\right)+\alpha_{2} \ln \left(\text { Baa10TR }_{t}\right)+\alpha_{3} O C_{t}+\varepsilon_{t}
$$

$$
\Delta \ln V 2_{t}=\beta_{0}+\beta_{1}\left(V 2_{t-1}-V 2_{t-1}^{*}\right)+\beta_{2} \Delta \ln \left(\operatorname{load}_{t-1}\right)+\beta_{3} \Delta \ln \left(\text { Baa10TR }_{t-1}\right)+\beta_{4} \Delta O C_{t-1}+\beta_{5} D_{t}+v_{t}
$$

\footnotetext{
25 Series are spliced where they overlap with a small additive adjustment (appendix B).

${ }^{26}$ In this manner, we seek an M2 measure as consistent as possible, over our entire sample, with the definition of M2 as currently published by the Federal Reserve Board of Governors.

${ }^{27}$ We also tested loads using a longer 5 year horizon and/or adjusted for expense ratios (see Duca, 2005). These other variants were significant but did not perform as well as the series used here which corresponds more closely with tracking asset transfer costs.
} 
We include several dummy variables, $D_{t}$, to capture unusual shocks to money demand, primarily special regulatory and monetary policy actions. ${ }^{28}$

The 1933 Bank Holiday: Beginning with the first bank crisis of October 1930, increased risk premia induced velocity declines early in the Great Depression; during 1932, velocity was threequarters of its 1929 level. ${ }^{29}$ Velocity increased in 1933, the year of Roosevelt’s Bank Holiday, even as the level of M2 averaged lower during the year. One reason perhaps was that commercial bank depositors experienced losses of 2.15 percent (Friedman and Schwartz, 1963, p. 438) in this pre-deposit insurance era, directly reducing M2 and inducing households to shift toward currency. ${ }^{30}$ Another, perhaps, was the belief before the Bank Holiday that the relatively young Federal Reserve would intervene to prevent the suspension of deposits. That belief, if crushed by repeated bank runs and the suspension of failed banks, might have lowered the demand for money until the start of FDIC insurance in 1934. To examine this effect, the model includes a BankHoliday dummy equal to 1 in 1933, and 0 otherwise.

Deflation also is a special event that might shift confidence. Conventional measures of M2's opportunity cost embody the impact of inflation on money demand via the expected inflation embedded in nominal interest rates. The zero lower bound on nominal interest rates prevents these measures from doing the same during periods of deflation. To examine this effect, the model includes a dummy (DeflationPCE) equal to 1 in years when year-over-year inflation as

\footnotetext{
${ }^{28}$ Below, we discuss the extent to which these same events might be captured in other explanatory variables, such as interest rates.

${ }^{29}$ Although nominal M2 in 1932 was 75 percent of its 1929 level, "real” M2 (adjusted by the GDP price deflator) was 98.5 percent of its 1929 level. Friedman and Schwartz (1963), ch. 7, note that the 1930 banking crisis was as severe as most during the nineteenth century and, absent the presence of the Federal Reserve, likely would have resulted in a restriction of the convertibility of deposits into currency. It is unreasonable to argue that the crisis did not increase risk premia for bank deposits.

${ }^{30}$ Friedman and Schwartz (1963), ch. 8, note that most licensed banks resumed business after the bank holiday without significant restriction, but unlicensed banks (more than 5,000 at the time of the holiday) were slow to reopen and almost half never reopened. The mythology enshrined in many money and banking texts is that depositors suffered large losses during the early 1930s; in fact, the losses were small. Repeated bank runs perhaps were the larger cause of increases in the public's risk premia.
} 
measured by the personal consumption expenditure price index was negative (1930-33, 1937, 1938, 1949, and 2009).

The 1951 Treasury-Fed Accord: The Federal Reserve had acted from 1942-1952 to sustain (“peg”) short- and long-term Treasury rates at low levels. An inflation spike following the end of WWII price controls and a second spike in the first year (1950) of the Korean War risked undermining the Federal Reserve's inflation credibility. Plausibly, by reestablishing monetary independence, the Accord enhanced M2 as a store of value. To examine this effect, the model includes a dummy (Accord) equal to 1 in 1951

Garn-St. Germain and MMDA: Changes in banking regulations can alter the attractiveness of money relative to other assets. Because bank offering rates on money market deposit accounts (MMDA), introduced in 1983 via the Garn St. Germain Act, were allowed to track market interest rates, the accounts could attract funds from non-M2 assets (see Small and Porter, 1989, and Duca, 2000; Lucas and Nicolini, 2014). To examine this effect, we include a dummy variable (DMMDA = 1 in 1983) for the introduction of MMDA deposits in 1983.

Dodd-Frank Act: The Dodd-Frank Act (DFA) of 2010 is another regulatory change that likely affects money demand and lowers velocity. Aspects of DFA, including requiring banks to retain some loss exposure in securitized loans and requiring "systemically important" banks and nonbanks to pass "stress tests," tend to reduce the attractiveness of the shadow banking system as financial intermediaries relative to chartered commercial banks (Duca, forthcoming). As a result, the traditional regulated banking system is likely to increase in size relative to the shadow banking system. Because M2-type instruments are a major source of funding for banks but not for shadow banks, this effect of DFA portends a lower velocity of M2. To examine this effect, we include a dummy (DFA) equal to 0 before 2010, .25 in 2010 (DFA was passed in summer 
2010) and 1 thereafter. Since this level shift occurs at the end of the sample, we anticipate that it will be difficult to identify, partly as M2 was affected by the 2011 change in the assessment of FDIC insurance premiums that induced banks to shift deposits booked overseas to onshore (Kreicher, et al., 2013; Judson, et al., 2014). Further, because regulatory reform was widely anticipated after the global financial crisis, the effect of DFA may be difficult to capture with any auxiliary variable.

\section{Stationarity}

We examine the covariance stationarity of our variables via ADF test statistics in Table 1. The tests fail to reject the hypothesis that the levels display unit root behavior but the differences do not (i.e., are I(0) stationary) for the log of nominal M2 (m), the log of the GDP price deflator (p), the log of nominal GDP (y), the log of M2 velocity (v), M2's opportunity cost measured relative to yields on short-term Treasury securities, stock mutual fund loads, the log of the BaaTreasury spread, and real M2 (m-p). Below, we conclude that a single cointegrating vector exists for eq. (9a). We also accept that two stochastic intervention variables that enter into the dynamic model, eq. (9b), are covariance stationary: OCST, the opportunity cost of M2 measured relative to stock returns, and YC, the slope of the Treasury yield curve (10-year - 3-month rates).

\section{Model Estimates}

Eight variants of equations (9a, b) are presented in Table 1 . The models differ with respect to sample periods, explanatory variables, and short-run controls (dummy variables). All models include six individual-year dummies to control for WW II effects during 1941-46. ${ }^{31}$ All models are estimated with a lag length of 4, leaving a "full-sample" period of 1932-2014. The lag length was chosen judgmentally according to three criteria: a unique cointegrating vector, a

\footnotetext{
${ }^{31}$ The six variables are simple binary dummy variables. For example, $D_{i}=1$, if year is 1941 ; $=0$ otherwise. Variables for 1942-1946 are specified similarly.
} 
rapid speed of adjustment, and clean residuals. No time trend was included in the models' cointegrating vectors, but time trends are permitted in the dynamic model.

The models shown in columns 1, 2, 3, 6 and 7 assert a long-run equilibrium that includes M2's opportunity cost, the corporate-Treasury yield spread, and stock fund loads. The model in column 4 specifies a long-run equilibrium that omits stock fund loads; the models in columns 5 and 8 omit stock fund loads and the corporate-Treasury yield spread. The short-run dynamic models in columns 1, 2, 4, 5, and 8 include a full set of short-run variables, the model in column 3 omits the bank regulatory dummy variables, and the models in columns 6 and 7 omit the DoddFrank dummy variable. Models also differ by sample period: the models in columns 1, 3, 4, 5, 7, and 8 are estimated using the full sample, the models in columns 2 and 6 use a shorter sample.

The purpose of Model 2 is to assess the robustness of Model 1's coefficients to events beginning 2006 that foreshadowed the recent financial crisis. Model 3 seeks to assess the robustness of the long-run coefficients to the exclusion of most of the non-WW II short-run variables in model 1 except for the opportunity cost terms with respect to Treasury bonds (YC) and stocks (OCST) and the DFA variable that controls for a regime change at the end of sample. Model 4 seeks to assess the robustness of Model 1 to omission of the stock fund load series; model 5 omits both stock fund loads and the corporate bond spread. Model 6, estimated through 1998, seeks to assess to what extent Model 2's estimates might be affected by the large rise and sudden fall of U.S. stock prices around the year 2000-date change and by the recent financial crisis. Models 7 and 8 are variants of models 1 and 3 that replace nominal GDP with nominal gross domestic income (GDI). Because GDI has recently grown faster than GDP, later benchmark revisions to GDP could alter coefficient estimates. Benchmark revisions usually narrow discrepancies between the income (GDI) and product sides of the NIPA accounts. 
A unique and statistically significant cointegrating vector was identified in Models 1-3 and 5-8. The estimated coefficient on each of the long-run terms was highly significant with the expected sign. Higher stock fund loads and higher corporate risk spreads reduce velocity because higher asset transfer costs lower the liquidity of non-M2 assets and raise the demand for M2. In contrast, higher opportunity costs of M2 with respect to Treasury bill rates $(O C)$ reduce the incentive to hold M2 balances, increasing velocity. The VECM coefficients on the errorcorrection term in regressions of the other three long-run variables indicate that they are weakly exogenous to velocity, implying that long-run trends in risk premia, mutual fund costs, and conventional M2 opportunity costs move temporally ahead of those in velocity (Granger and Lin, 1995). We note that $O C$ is not statistically significant in the models that omit stock fund loads $(4,5,8)$ or bond risk premia (models 5 and 8), plausibly reflecting omitted variable bias from excluding the statistically significant impacts of asset transfer costs and risk premia on velocity..

Within the set of models that include all three long-run determinants of velocity $(1,2,3$, 6, and 7), the coefficients on conventional opportunity costs, stock fund loads and corporateTreasury yields spreads are very similar. We conclude that our baseline specification is robust to both whether it is estimated over a pre-crisis or post-crisis sample and to whether it includes short-run variables that control for unusual financial/regulatory/regime shocks (BankHoliday, DumAccord, DMMDA, and DFA) or a deflation (DeflationPCE).

Among the models that include a full set of short-run controls and are estimated over the full sample $(1,4,5)$, model 1 outperforms models 4 and 5-which omit stock fund loads-in several dimensions. First, in model 1, the coefficient on $O C$ is highly significant at the 99 percent confidence level and its estimated value is similar in size to those in models 2 and 3 . The estimated OC coefficients in models 4 and 5 are not statistically significant. Second, the error- 
correction coefficient for model 1 is about three times as large as that for models 4 and 5 . The coefficient estimate for model 1 implies that the current year change in velocity tends to remove 32 percent of the gap between actual and equilibrium velocity from the prior year. Hence, the discrepancy between actual velocity, V2, and its estimated equilibrium level, V2*, is largely eliminated in a plausible four-year time span rather than the implausibly long ten year spans suggested by models 4 and 5 . Third, the fit of model 1 is higher than that of models 4 and 5 , judged by the corrected $\mathrm{R}^{2}$. This reflects information from stock fund loads (and compared to model 5, also from corporate bond spreads) coming through the error-correction term and lagged first differences. As illustrated earlier in Figure 1, the implied equilibrium level of velocity from model 1 tracks actual velocity well, particularly if the path is adjusted for the medium-run effects of WWII and the post-DFA financial regulatory regime. Similar qualitative results were obtained when velocity is defined using GDI instead of GDP in models 7 and 8, which correspond to Models 1 and 5, respectively.

The short-run variables, other than the WWII controls and lagged first difference terms of long-run vector variables, serve several roles. Two control for the short-run influences of money opportunity costs vis-à-vis stocks (OCST) and long-run Treasury bonds (YC), as suggested by Friedman and Schwartz. Because their inclusion helps complete the specification's coverage of major substitution effects, they are included in all models. The variable tracking opportunity costs with respect to stocks (OCST) is highly significant in every regression, with higher values raising velocity via lowering money demand. The opportunity cost term tracking the Treasury yield curve slope, YC, has the expected positive sign, but at best is only marginally significant in three of eight models. In contrast, DeflationPCE which tracks deflationary episodes is highly significant with a negative estimated effect of minus 4 to 5 percent. Together with the 
significant impact of the conventional opportunity cost term, this finding is consistent with the view that price changes influence money demand in ways that are normally tracked by traditional opportunity cost measures but not during periods of deflation.

To control for a likely regime shift at the end of the sample, each full sample model includes the DFA to track how the Dodd-Frank Act has helped to shrink the relative size of the shadow banking sector (Duca, forthcoming) and indirectly boost the size of the banking sector that relies on M2 deposits for much of its funding. In other models that omit DFA, other estimated coefficients are similar, but serial correlation arises in the residuals. This likely reflects that the Dodd-Frank Act effectively has imparted a persistent upward shift in money demand (and a downward shift in velocity) by altering the architecture of financial intermediation.

The inclusion of the other short-run variables also helps address serial correlation in residuals without affecting long-run coefficients, but that arising from shorter-lived shocks. For example, while the long-run coefficients in models 1 and 3 are similar, the residuals are not clean for model 3, which omits several short-run variables in model 1 . Among these variables are the dummy for the Bank Holiday of 1933 (BankHoliday), which has the expected positive sign and is statistically significant with a large sized estimated effect (4 to 9 percent) in most regressions. Another variable, DMMDA, which tracks the short-run effect of introducing MMDAs in late 1982 and early 1983 has the expected negative sign, but is insignificant in the models that include it with an estimated effect of 2 to 5 percent (0.05 in a log specification). The variable for the short-run effect of the Treasury-Fed Accord (DumAccord) also has the expected negative effect on velocity, plausibly reflecting how it may have bolstered money demand by increasing Fed independence. Nevertheless, its effect is at best only marginally significant in two of the 
three models that include the corporate bond spread and stock mutual fund load series. Comparing models 1 and 3 indicates that inclusion of these four short-run variables jointly increases the corrected R-square by a sizable 6 percent, while eliminating short-run serial correlation at a lag length of two.

\section{Simulating Nominal GDP After the Great Recession}

An important aspect of our analysis is to address this question: When economic activity returns to more "normal” levels and risk premia revert to more normal levels, what growth of the broad money supply will be consistent with low, stable inflation? We emphasized above that the historical record with regard to answering this question is slight—-the 2008 financial crisis has as its precedent the Great Depression of the 1930s — and the historical record muddied by the interaction between broad money's changing opportunity cost and the wide fluctuations of risk premia during periods of financial stress.

The macroeconomic significance of our in-sample results with regard to providing answers for this question might be assessed via simulations of velocity, thereby drawing out its implications for nominal GDP under different scenarios for M2 growth and under a common set of assumed future values for key variables that affect velocity. Herein, for BaaTR, we used average Blue Chip Financial forecasts (from August 2014) of the Baa Corporate rate and Congressional Budget Office forecasts of 10-year Treasury yields for 2014 and 2015. We construct a BaaTR path through 2019 by assuming that BaTR will fall 0.1 percentage points during that period, converging to its 1970-2006 average spread of 2.0 percent. For the yield curve spread, we used CBO forecasts of the 3-month and 10-year Treasury yields. We assumed that $O C$ would rise 0.1 percentage points per year to level out at 0.4 points. 
We use coefficient estimates from model 1 to construct a forecast of equilibrium velocity from 2015-19 before adjusting for DFA effects. To adjust for the future impact of DFA implementation on the log level of velocity, we treated the year estimated coefficient on the DFA dummy (equal to .25 in 2010, 1 in 2011-2014, and 0 thereafter) as a current year impact factor, to which we added the prior year's estimated level effect multiplied by one minus the estimated error correction speed. By construction, we effectively assume a roughly 30 percent annual adjustment speed, which translates into a 4 year transition to a DFA regulated world. Essentially, DFA permanently lowers log velocity by a sizable 0.22 . The resulting path in Figure 12 shows a mild upturn in V2* during 2016 and 2017, before leveling off. Since V2 adjusts with a lag, this suggests a delayed uptick in V2 before accounting for other short-run dynamics.

As a partial equilibrium simulation, we multiply this equilibrium path for velocity by different paths for M2 under the assumptions of continued near 6.5 percent M2 growth through 2019, as well as for 5 and 4 percent growth paths. This produces levels of simulated equilibrium nominal GDP, from which we compute simulated growth rate paths for equilibrium nominal GDP. As shown in Figure 13, a 6.5 percent M2 growth scenario induces about a 6 percent average path for nominal GDP over 2015-19, implying a mild acceleration of inflation. 5 percent M2 growth allows for enough near-term nominal GDP growth to enable a recovery to full employment, with about 2-1/2 percent inflation thereafter. Four percent M2 growth implies low-to-moderate nominal GDP growth, which is consistent with keeping long-run inflation at or just below 2 percent.

In addition to the static simulation of equilibrium V2, model 1 was dynamically simulated to account for both the delayed error-correction adjustment of V2 towards its equilibrium and the short-run dynamic effects of changes in its long-run determinants. As 
illustrated in Figure 14, the simulation suggests that M2 velocity will decrease in 2015, 2016, and 2017 by 1.75, 0.56, and 0.27 percent, respectively, before increasing in 2018, 2019, and 2020 by $0.66,1.1$, and 1.03 percent, respectively. The model's near-term prediction is confirmed by preliminary data: velocity during the first three quarters of 2015 was 2.1 percent lower than its four-quarter average in 2014. A near-term decrease in velocity might be welcomed by policymakers as they seek to shrink the Federal Reserve's balance sheet (and moderate M2 growth) during the return to a "normal" policy stance. The assumed or projected paths for the drivers of V2 are plotted in Appendix C, along with the residuals of the short-run changes in each element of the VECM system.

\section{Figure 12: M2 Velocity Likely to Stabilize} According to Static Simulations

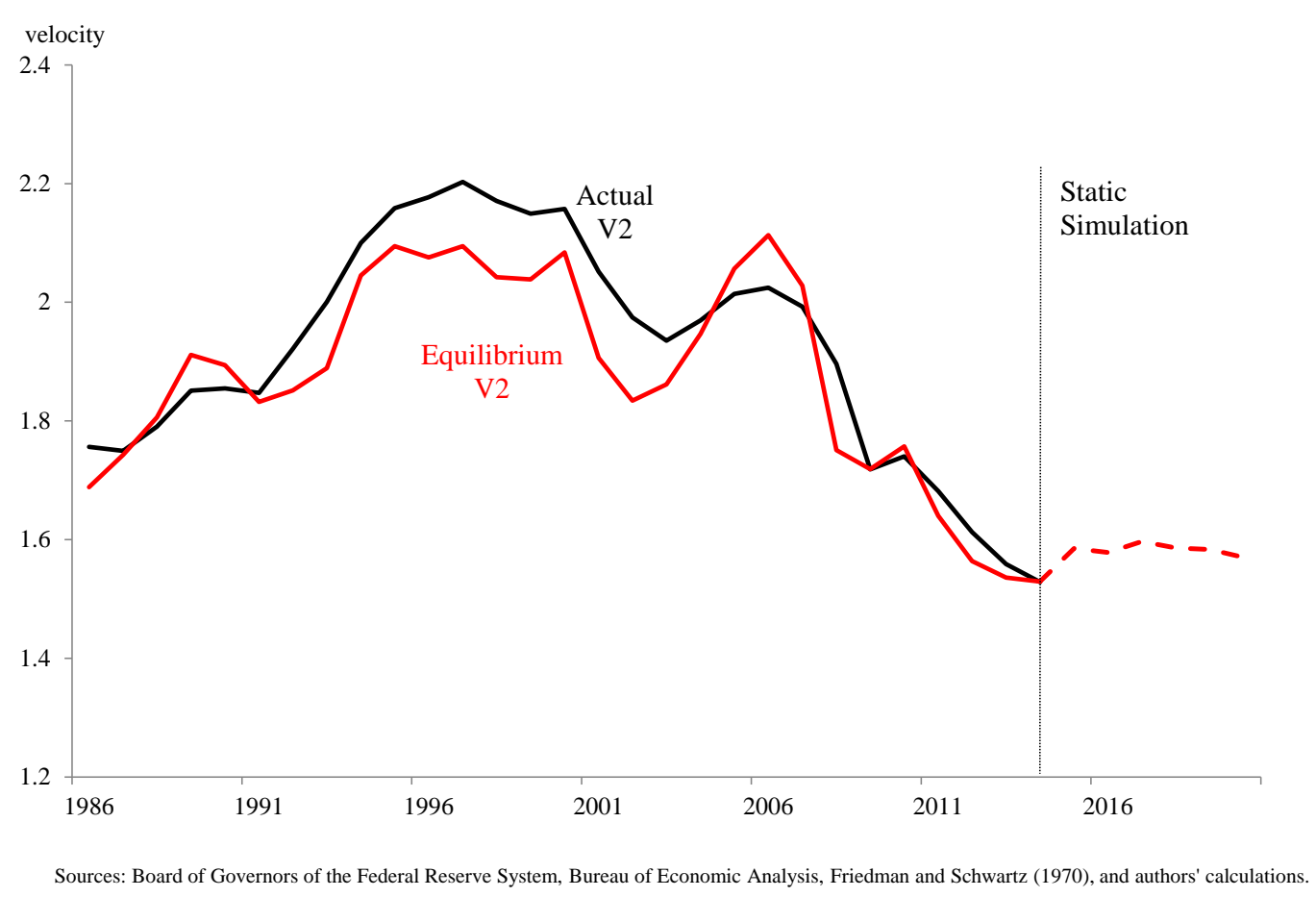


Figure 13: Nominal GDP Growth Paths Under Different M2 Growth Scenarios

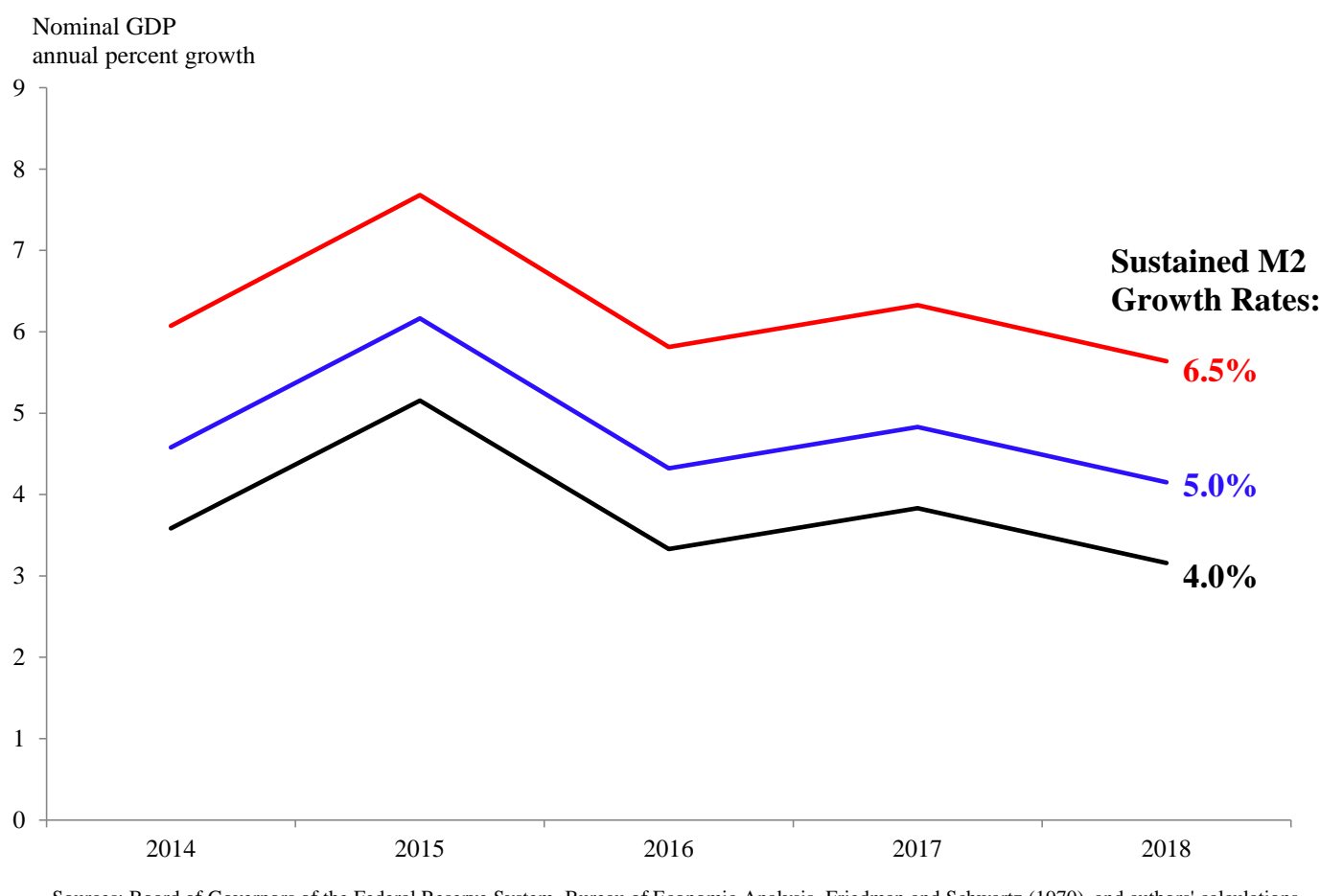

Figure 14: M2 Velocity Likely to Stabilize and Later Drift Upward Somewhat

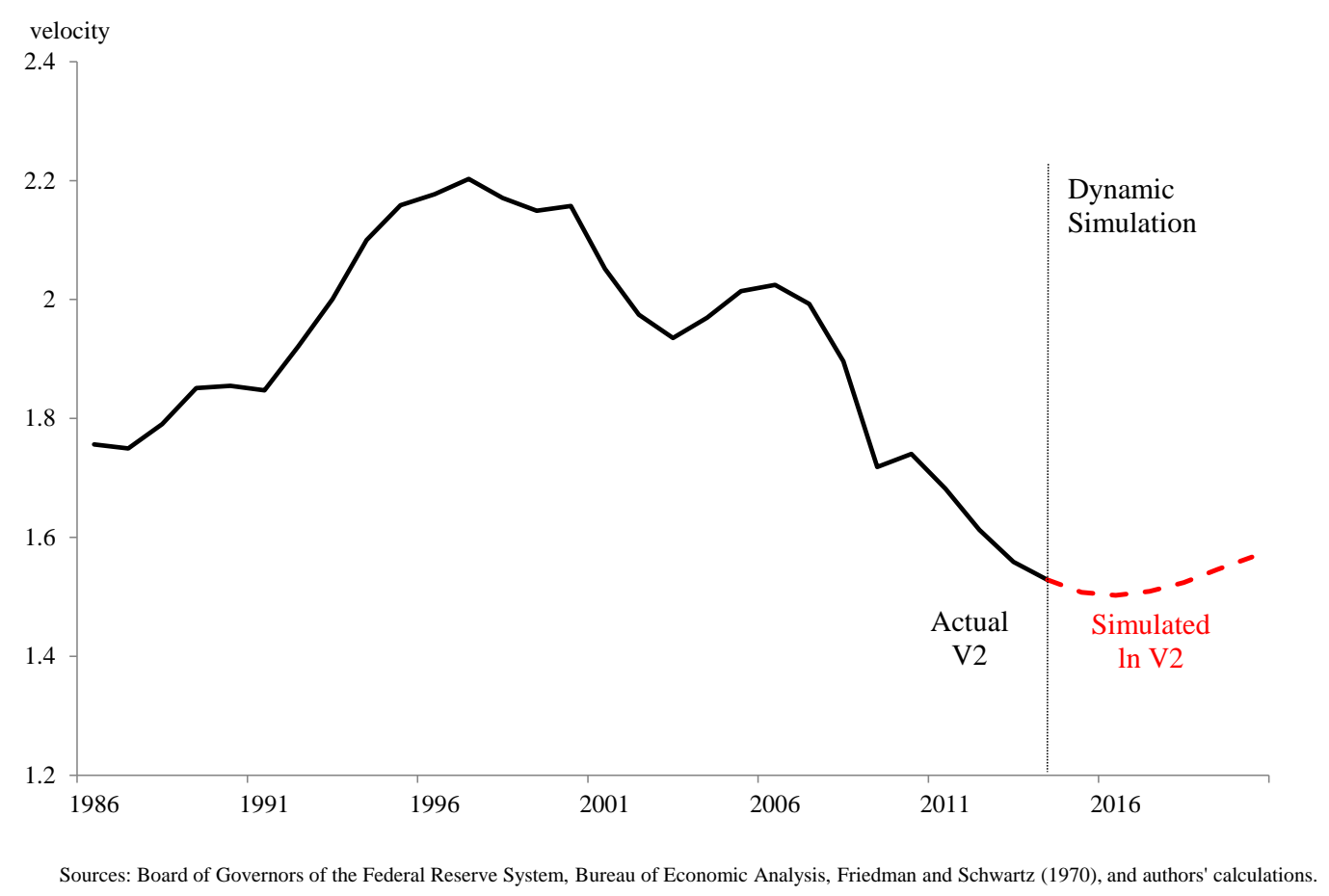




\section{Conclusion}

This study presents a model of U.S. broad money demand since the onset of the Great Depression. The model is able to track more than 80 years of money demand, through both the Great Depression and the Great Recession by incorporating interactions among three variables: (i) the traditional opportunity cost of M2, (ii) long-run declines in the transaction costs of using M2 substitutes, and (iii) a measure of financial market participants' perceived risk. All three variables are economically and statistically significant in our long-run model. Because all three are covariance non-stationary and mutually correlated, omitting any from the empirical model would cause an implicit nonstationary disturbance and inconsistent parameter estimates. We conjecture that past "velocity shifts” and cases of “missing M2" are statistical consequences of such miss-specification that arises from not fully accounting for these important determinants of money demand.

Because our estimated dynamic model tracks velocity well over the long time period spanning the two major U.S. financial crises of the past century, it can help extract information important to the conduct of monetary policy from movements in the path of a broad monetary aggregate. Models that accurately track M2 velocity are particularly valuable during periods when risk premia change quickly. Following crisis periods, economic activity is returning to normal but, at the same time, velocity is increasing as risk premia recede from crisis peaks. This is particularly relevant in comparing the Great Depression and the Great Recession. The starts of these crisis periods were marked by sharp increases in risk premia and decreases in velocity. One key difference is velocity recovered rapidly in the mid-1930s as risk premia retreated, whereas the recovery in velocity after the Great Recession was offset by the impact of the Dodd-Frank Act, which induced shifts into money from other assets by altering the structure of the U.S. banking and financial system, consistent with Bordo and Jonung (1987, 1990, 2004) and Duca 
(forthcoming). As illustrated in Figure 2, our model suggests that, absent the impact of DoddFrank and related regulatory changes, velocity likely would have recovered much as it did during the Great Depression. More specifically, average growth in M2 at a 6.5 percent annual rate since onset of the global financial crisis in 2007-08 did not translate into moderately strong nominal GDP growth in the United States because financial reform and risk premia effects worked to increase money demand and lower velocity. The estimated speeds of adjustment in our preferred model strongly suggest that further velocity declines from the Dodd-Frank act are not likely to continue. Indeed, simulations based on our model estimates indicate that velocity is likely to rise toward a somewhat higher equilibrium level in coming years, with dynamic simulations showing a smaller and later uptick in velocity than in static simulations. 


\section{References}

Acharya, Viral and Lasse Pedersen (2005). “Asset Pricing with Liquidity Risk.” Journal of Financial Economics. 77. 375-410.

Anderson, Richard G. (2003). “Some Tables of Historical U.S. Currency and Monetary Aggregates Data.” Federal Reserve Bank of St. Louis working paper 2003-006. April.

Anderson, Richard G. (1993), “The Effect of Mortgage Refinancing on Money Demand and Monetary Aggregates,” Federal Reserve Bank of St. Louis Review 75(4), 49-63.

Balke, Nathan S. and Robert J. Gordon (1986). “Appendix B,” in The American Business Cycle: Continuity and Change, R.J. Gordon, ed., University of Chicago Press. See also http://www.nber.org/data/abc/ .

Ball, Laurence (2001), “Another Look at Long-Run Money Demand,” Journal of Monetary Economics 47, 31-44.

Barsky, Robert, Alejandro Justiniano, and Leonardo Melosi (2014), “The Natural Rate of Interest and Its Usefulness for Monetary Policy Making,” American Economic Review Papers and Proceedings 104, 37-43.

Baumol, William (1952), “The Transactions Demand for Cash: An Inventory Theoretic Approach,” Quarterly Journal of Economics 66, 545-56.

Becsi, Zsolt and John V. Duca (1994), "Adding Bond Funds to M2 in the P-Star Model of Inflation," Economics Letters 46, 143-147.

Bernanke, Ben S. (2006). "Monetary Aggregates and Monetary Policy at the Federal Reserve: A Historical Perspective.” At the Fourth ECB Central Banking Conference, Frankfurt, Germany. November 10.

Board of Governors of the Federal Reserve System (2002), “Monetary Report to Congress.” 
Board of Governors of the Federal Reserve System (2004), "Monetary Report to Congress.”

Bordo, Michael D. and Joseph G. Haubrich (2012), “Deep Recessions, Fast Recoveries, and Financial Crises: Evidence from the American Record,” Federal Reserve Bank of Cleveland working paper 2012-14. June.

Bordo, Michael D. and Lars Jonung (2005), Demand for Money: An Analysis of the Long-Run Behavior of the Velocity of Circulation, Transactions Press, New Brunswick, N.J.

Bordo, Michael D., Jonung, Lars, and Pierre L. Siklos (1997), “Institutional Change and the Velocity of Money: A Century of Evidence,” Economic Inquiry 35, 710-24.

Bordo, Michael D. and Lars Jonung (1990), “The Long-Run Behaviour of Velocity. The Institutional Approach Revisited,” Journal of Policy Modeling 12, 165-97.

Bordo, Michael D. and Lars Jonung (1987), The Long-Run Behaviour of Velocity. The International Evidence, Cambridge University Press.

Brown, S.J., W.N. Goetzmann, and S.A. Ross (1995). “Survival.” Journal of Finance. 50:853-73. Brunner, Karl and Allan H. Meltzer (1966), “A Credit Market Theory of the Money Supply and and an Explanation of Two Puzzles in U.S. Monetary Policy,” in Bagiotti, T., ed., Investigations in Economic Theory and Methodology, Essays in Honor of Marco Fanno. Vol. 2. Padova: Cedam, 1966, 151-76. Reprint in Brunner, Karl and Allan H. Meltzer, Monetary Economics, Oxford: Basil Blackwell, 1989, 97-120.

Brunner, Karl and Allan H. Meltzer (1967), "Economies of Scale in Cash Balances Reconsidered,” Quarterly Journal of Economics 81, 422-36.

Brunnermeier, Markus K. and Yuliy Sannikov (2013), “The I Theory of Money,” manuscript, Princeton University, October.

Carlson, John B., Dennis L. Hoffman, Benjamin D. Keen, and Robert H. Rasche (2000), 
"Results of a Study of the Stability of Cointegrating Relations Comprised of Broad Monetary Aggregates,” Journal of Monetary Economics 46, 345-83.

CDA/Wiesenberger (a), Investment Companies, various annual issues, [CDA Investment Technologies: Rockville, Maryland, USA].

, (b) Mutual Funds Panorama, various annual issues, [CDA Investment Technologies: Rockville, Maryland, USA].

Clark, Todd, and Kozicki, Sharon (2004), “Estimating Equilibrium Real Interest Rates in Real Time,” FRB Kansas City Working Paper 2004-08, (September) http://www.kansascityfed.org/Publicat/Reswkpap/pdf/RWP04-08.pdf

Cochrane, John H. (1994) "Permanent and Transitory Components of GNP and Stock Prices," Quarterly Journal of Economics 109, 241-63.

Committee on Banking and Currency (1935). Summary of statements by Marriner S. Eccles, governor of the Federal Reserve Board, in reply to questions posed by members of the Committee on Banking and Currency of the House of Representatives, at hearings on The Banking Bill of 1935. March 4-20, 1935.

Cuthbertson, Keith (1985), The Supply and Demand for Money, New York: Basil Blackwell.

Cuthbertson, Keith (1997), "Microfoundations and the Demand for Money,” The Economic Journal, 107, pp. 1186-1201.

Darby, Michael R. (1976), "Three-and-a-Half Million U.S. Employees Have Been Mislaid: Or an Explanation of Unemployment, 1934-1941," Journal of Political Economy 84, 1-16.

Davis, M.H.A. and A.R. Norman (1990), "Portfolio Selection with Transactions Costs," Mathematics of Operations Research 15, 676-713. 
Dotsey, Michael and Andreas Hornstein (2003), "Should a Monetary Policymaker Look at Money?” Journal of Monetary Economics, 50, 547-579.

Dow, James P., Jr, and Douglas W. Elmendorf (1998), "The Effect of Stock Prices on the Demand for Money Market Mutual Funds,” Board of Governors of the Federal Reserve System, Finance and Economics Discussion Series 98-24.

Duca, John V. (1994), "Would the Addition of Bond or Equity Funds Make M2 a Better Indicator of Nominal GDP?” Federal Reserve Bank of Dallas Economic Review, Q4.

Duca, John V. (2000), “Financial Technology Shocks and the Case of the Missing M2,” Journal of Money, Credit, and Banking 32, 820-39.

Duca, John V. (1990), “The Impact of Mortgage Activity on Recent Demand Deposit Growth,” Economics Letters 32, 157-61.

Duca, John V. (2003), “Stock Market Shocks and Broad Money Demand,” manuscript, Federal Reserve Bank of Dallas, July.

Duca, John V. (2006), "Mutual Funds and the Evolving Impact of Stock Wealth on U.S. Consumption,” Journal of Economics and Business 58, 202-21.

Duca, John V. (2005), "Why Have Households Increasingly Relied on Mutual Fund Loads to Own Equity?” Review of Income and Wealth 51 (3) (September 2005), 375-96.

Duca, John V. and David D. VanHoose (2004) "Recent Developments in Understanding the Demand for Money,” Journal of Economics and Business 56, 247-72.

Duca, John V. and John Muellbauer (2013), “Tobin Lives: Integrating evolving credit market architecture into flow of funds based macro-models,” ECB Working Paper No. 1581.

Duca, John V. (forthcoming), "How Capital Regulation and Other Factors Drive the Role of 
Shadow Banking in Funding Short-Term Business Credit,” Journal of Banking and Finance.

Fama, Eugene and Kenneth French (2001), "Disappearing Dividends: Changing Firm Characteristics or Lower Propensity to Pay,” Journal of Financial Economics 60, 3-43.

Federal Open Market Committee (2015), “Statement on Longer-Run Goals and Monetary Policy Strategy,” amended, January 27, 2015.

Fleissig, Adrian R. and Barry Jones (2015). “The Impact of Commercial Sweeping on the demand for monetary assets during the Great Recession.” Journal of Macroeconomics, 45(C) 412-422.

Ford, James L. and Andrew Mullineux (1996). "Financial Innovation and monetary aggregates in the UK, 1977-93,” in A. Mullineux, ed., Financial Innovation, Banking and Monetary Aggregates, pp. 13-38. Edward Elgar.

Friedman, Milton and Anna J. Schwartz (1963), A Monetary History of the United States 18671960, Princeton, Princeton University Press.

Friedman, Milton and Anna J. Schwartz (1970), Monetary Statistics of the United States: Estimates, Sources, Methods. Columbia University Press for the NBER.

Friedman, Milton and Anna J. Schwartz (1982), Monetary Trends in the United States and the United Kingdom: Their Relation to Income, Prices, and Interest Rates. University of Chicago Press for the NBER.

Friedman, Milton, (1956), “The Quantity Theory of Money—A Restatement,” in M. Friedman (ed.), Studies in the Quantity Theory of Money. Chicago: University of Chicago Press.

Friedman, Milton, (1988), "Money and the Stock Market,” Journal of Political Economy 96, 221-45. 
Goetzmann, William N. and Roger G. Ibbotson (2008). “History and the Equity Risk Premium.” in Mehra (2008), chapter 12.

Gramley, Lyle E. (1982), Statement before the Subcommittee on Domestic Monetary Policy, Committee on Banking, Finance and Urban Affairs, U.S. House of Representatives. March 3.

Granger, Clive W.J. and Jin-Lung Lin (1995), “Causality in the Long-Run,” Econometric Theory $11,530-536$.

Hallman, Jeffrey J., Richard D. Porter, and David H. Small (1991), "Is the Price Level Tied to the M2 Monetary Aggregate in the Long Run?” American Economic Review 81, 841-58.

Hamburger, Michael J. (1977), “Behavior of the Money Stock: Is There a Puzzle?” Journal of Monetary Economics 3, 265-88.

Hamburger, Michael J. (1966), “The Demand for Money by Households, Money Substitutes, and Monetary Policy,” Journal of Political Economy 74, 600-23.

Heaton, John and Lucas, Deborah (2000), "Portfolio choice in the presence of background risk," The Economic Journal 110, 1-26.

IBC/Donoghue, Mutual Funds Almanac, various annual issues, [IBC/Donoghue: Ashland, Massachusetts, USA].

Ireland, Peter N. (1995). "Endogenous Financial Innovation and the Demand for Money," Journal of Money, Credit and Banking, 27(1) 107-123.

Jalil, Andrew and Gisela Rua (2015), “Inflation Expectations and Recovery from the Depression in 1933: Evidence from the Narrative Record,” Board of Governors of the Federal Reserve System, unpublished manuscript. 
Judson, Ruth, Bernd Schlusche, and Vivian Wong (2014), "Demand for M2 at the Zero Lower Bound: The Recent U.S. Experience.” Finance and Economics Discussion Series paper 2014-22, Federal Reserve Board, Washington, D.C., January.

Kejriwal, Mohitosh and Pierre Perron (2010), "Testing for Multiple Structural Changes in Cointegrated Regression Models," Journal of Business and Economic Statistics 28, 50322.

Kreicher, Lawrence L., Robert N. McCauley, and Patrick McGuire (2013). “The 2011 FDIC assessment on banks’ managed liabilities: interest rate and balance-sheet responses.” BIS Working Paper 413. May.

Keynes, John M. (1935), The General Theory of Employment, Interest, and Money, New York: Harcourt, Brace, and World.

Kim, Jinill (1998), “Monetary Policy in a Stochastic Equilibrium Model with Real and Nominal Rigidities,” Finance and Economics Discussion Series Paper No. 1998-02, Federal Reserve Board.

Kreicher, Lawrence L., McCauley, Robert N., and Patrick McGuire (2013), “The 2011 FDIC assessment on banks’ managed liabilities: interest rate and balance sheet responses,” BIS Working Paper No. 413.

Laidler, David E. (1969), The Demand for Money. Scranton, Pa: International Textbook Company.

Laubach, Thomas and Williams, John (2004), "Measuring the Natural Rate of Interest," The Review of Economics and Statistics 85, 1063-70.

Liu, Hong (2004), “Optimal Consumption and Investment with Transaction Costs and Multiple Risky Assets,” Journal of Finance 59, 289-338. 
Liu, Hong and Loewenstein, Mark (2002), “Optimal Portfolio Selection with Transactions Costs and Finite Horizons,” The Review of Financial Studies 15 (Summer 2002), 805-35.

Lucas, Robert E. (1988), "Money Demand in the United States: a Quantitative Review," Carnegie-Rochester Conference Series on Public Policy 29, 137-68.

Lucas, Robert E. and Juan Pablo Nicolini (2014), “Monitoring Money for Price Stability,” paper presented at the $84^{\text {th }}$ meeting of the Carnegie-Rochester-NYU Conference Series on Public Policy. November.

McCallum, Bennett T. (1997), “The Alleged Instability of Nominal Income Targeting,” NBER Working Paper No. 6291.

McCallum, Bennett T. (2000), “Alternative Monetary Policy Rules: A Comparison with Historical Settings for the United States, the United Kingdom, and Japan.” Federal Reserve Bank of Richmond Economic Quarterly. 86. 49-79.

McCallum, Bennett T. (2001), “Monetary Policy Analysis in Models without Money,” Federal Reserve Bank of St. Louis Review, 83, 4 (July/August)

McCallum, Bennett T. and Edward Nelson (2010). "Money and Inflation: Some Critical Issues,” in Benjamin M. Friedman and Michael Woodford, eds., Handbook of Monetary Economics. Volume 3, 98-153.

Mehra, Rajish (2008), ed. Handbook of the Equity Risk Premium. Elsevier North-Holland.

Meltzer, Allan H. (1998), "Monetarism: The Issues and the Outcome," The Atlantic Economic Journal 26, 8-31.

Moore, George, Richard Porter and David Small (1990), "Modeling the Disaggregate Demands for M2," in Financial Sectors in Open Economies (Board of Governors of the Federal Reserve System). 21-105. 
Morningstar, Morningstar Mutual Funds, various issues.

Mulligan, Casey B. and Xavier Sala-i-Martin (1996), “Adoption of Financial Technologies: Implications for Money Demand and Monetary Policy,” NBER Working Paper No. 5504.

Mulligan, Casey B. and Xavier Sala-i-Martin (2000), "Extensive Margins and the Demand for Money at Low Interest Rates,” Journal of Political Economy 108(5), 961-991.

Nelson, Edward (2003), "The Future of Monetary Aggregates in Monetary Policy Analysis," Journal of Monetary Economics, 50, 3, 1029-59 (July).

Orphanides, Athanasios, Brian Reid and David Small (1994). "Empirical Properties of a Monetary Aggregate that Adds Bond and Stocks Funds to M2.” Federal Reserve Bank of St Louis Review. November/December.

Orphanides, Athanasios (2015), “Fear of Liftoff: Uncertainty, Rules, and Discretion in Monetary Policy Normalization,” Federal Reserve Bank of St Louis Review. Third Quarter.

Orphanides, Athanasios and Richard D. Porter (2000), "P* Revisited: Money-Based Inflation Forecasts with a Changing Equilibrium Velocity,” Journal of Economics and Business 52, $87-100$.

Pastor, L. and R. Stambaugh (2003). Liquidity Risk and Stock Returns.” Journal of Political Economy. 11. 642-685.

Rasche, Robert H. (1987). "M1 Velocity and Money Demand Functions: Do Stable Relationships Exist?” Carnegie-Rochester Conference Series on Public Policy 27, 9-88.

Rasche, Robert H. (1990). “Demand Functions for Measures of U.S. Money and Debt.” in Financial Sectors in Open Economies (Board of Governors of the Federal Reserve System). 113-161.

Rocheteau, Guillaume and Randall Wright (2013), “Liquidity and Asset-Market Dynamics,” 
Journal of Monetary Economics. 60. 275-294.

Rockoff, Hugh (1981), "Price and Wage Controls in Four Wartime Periods," Journal of Economic History 41, 381-401.

Shiller, Robert J. (2014), “Online Stock: U.S. Stock Markets 1871-Present and CAPE Ratio,” $<$ http://www.econ.yale.edu/ shiller/data/ie_data.xls $>$

Small, David H., and Richard D. Porter (1989), "Understanding the Behavior of M2 and V2,” Federal Reserve Bulletin 75, 244-54.

Svensson, Lars (2009), "Monetary policy with a zero interest rate,” address to Centre for Business and Policy Studies, Stockholm, Feb. 2, 2009. http://www.riksbank.se/en/Pressand-published/Speeches/2009/Svensson-Monetary-policy-with-a-zero-interest-rate/

Tobin, James (1956), “The Interest Elasticity of Transactions Demand for Cash,” Review of Economics and Statistics 38, 241-47.

Tobin, James (1958), "Liquidity Preference as Behavior Toward Risk," Review of Economic Studies 25, 65-86.

Wang, Yiming (2011), "The stability of long-run money demand in the United States: A new approach,” Economics Letters 111, 61-63.

Williamson, Stephen and Randall Wright (2010), "New Monetarist Economics: Models,” in Benjamin M. Friedman and Michael Woodford, eds., Handbook of Monetary Economics. Volume 3, 25-96.

Woodford, Michael (2003). Interest and Prices. Princeton University Press.

Zakamouline, Valeri I. (2002), “Optimal Portfolio Selection with Transactions Costs for a CARA Investor with Finite Horizon,” unpublished manuscript, (December 2002), http://www.nhh.no/for/dp/2002/2002.pdf. 


\section{Appendix A: Mutual Fund Data}

Because data before the mid-1980s are sketchy and incomplete, mutual fund cots were based on a sample of large mutual funds. Funds were selected if their assets were at least \$1 billion at year-end 1991 if the fund existed before the mid-1980s; were at least $\$ 2$ billion at yearend 1994 if the fund's inception date occurred after 1983; were at least \$5 billion at year-end 2003; or were at least $\$ 250$ million at year-end 1975. The first criterion reflects whether a fund was sizable during early missing M2 period of the early 1990s. The second criterion reflects whether a growing but new fund was large near the end of the missing M2 period. The third criterion reflects whether a fund remained large following the stock market bust of the early 2000s. Given the stock and bond appreciation of the early 1990s, the hurdles for newer funds were higher for the 1994 and 2003 cutoff dates to keep data gathering costs from exploding. The fourth criterion avoids excluding funds that were relatively large in 1975 from distorting averages when fewer funds existed. Also excluded were funds that were closed-end, only open to employees of a specific firm, or institutional. Also omitted are funds with high minimum balances $(100,000$ or more) because such high hurdles make such funds poor substitutes for M2, which is predominantly held by middle income households. 46 non-municipal bond and 133 equity mutual funds are in the sample (a list is available from the author) using data from the funds and various issues of Morningstar, IBC/Donoghue, and CDA/Wiesenberger (a, b). The

aggregate load series are based on using the size of net assets under management of a fund relative to the sum of all assets managed by funds in the sample. Year-end asset data are available since 1946.

For each year over 1926-45 we proxied asset weights on each fund by its 1946 asset weight divided by the sum of all 1946 asset weights for funds that in operation after the year of 
their inception. For the years before and during a fund's inception its 1946 weight is replaced by zero. These proxied asset weights are combined with front-end loads levied by the funds (there were no funds charging deferred or back-end loads until the 1980s). Since most funds operating before 1946 charged loads between 6.5 and 8.5 percent, with the largest fund (Massachussetts Investors Trust) levying 7.5 percent, the annual weighted average load series SLD1 fluctuated in a narrow range between 7.5 and 7.8 percent over 1926-45, much as it did over 1946-1959. This suggests that the use of proxied annual asset weights before 1946 had a minimal effect on the resulting annual aggregate series. Annual expense ratios before 1946 were not available and pre1945 expense ratios were assumed to equal their 1946 levels. As with the load series, the annual average expense ratios for 1926-45 were similar to those seen over 1946-59. Moreover, the analysis focuses on using the load series without expense ratio adjustments—as it performed better than an expense-adjusted series, consistent with the non-adjusted series entering the money demand (velocity) specifications mainly as a proxy for asset transfer costs. 


\section{Appendix B: Historical Own Rates of Return on M2 and M2 Opportunity Costs}

Conventional measures of the opportunity cost of M2 equal an average "own rate" of return on M2 minus a risk-free short-term interest rate. For the latter we spliced 1927-33 data on the average short-term (three to six months) Treasury interest rate (NBER MacroHistory DataBase) with the three month Treasury interest rate converted from a discount basis (360 days per year) to a 365 day basis. Consistent measures of the own rate of return on M2 are available from 1958 to present (source: Federal Reserve Bank of St. Louis), necessitating the construction of earlier readings. Pre-1958 readings equal the non-currency share of M2 multiplied by the average interest rate paid on deposits at financial intermediaries (banks, S\&Ls, credit unions and mutual savings banks), which in turn equals the deposit-weighted average interest rate paid on demand and time deposits.

\section{Average Interest Rates on M2 Balances}

Prior to the Federal Reserve's September 1933 implementation of the Banking Act of 1933 banks were allowed to pay interest on the demand deposits and between 1933 and 1939, there were a small and declining number of grandfathered account balances which could offer the interest. Note that the distinction between demand and time deposits was more ambiguous in the 1930s than in more recent decades because it was not until the mid-1930s that the Federal Reserve started imposing different reserve requirement ratios on the two deposit types. Hence the distinction between M1 and nonM1 M2 deposits was less clear-cut and this measurement issue was among the reasons Friedman and Schwartz preferred M2 over M1. Using data from active (i.e., not suspended) national bank mid-year reports to the OCC, the average annual interest rate on demand deposits equaled the total interest paid over the prior 12 months on 
demand deposits divided by average of mid-year demand deposit balances for years t and t-1. This average rate fell from a peak of 1.21 percent in 1929 to 0.01 in 1938 and 0 thereafter.

The average annual interest rate on time deposits equaled the total interest paid over the prior 12 months on time deposits divided by the mid-year total of time deposits using national bank mid-year reports to the OCC until 1939, and from 1940-58 the average time deposit rate equaled the December reported annual total of interest paid divided by the average deposit level for that year-approximated by the average of the year $t$ and $t-1$ December deposit balances. Thrift institutions (mutual savings banks, savings and loans, and credit unions) typically offered either a common share or several time deposit accounts, which typically offered somewhat higher interest rates on what are typically classified as time or savings deposits. The interest rate on share deposits at mutual savings banks (MSBs), for example, typically exceeded the average time deposit rate paid at commercial banks using interest rate data at MSBs available before 1930 and after 1945. For this reason, our measure of time deposit rates and the average own rate on M2 (available using published data from the OCC up to 1964), while consistently measured over time for national (commercial) banks, likely understates what a more ideal and comprehensive series spanning commercial banks and thrift institutions, such as that from the Federal Reserve System.

Consistent with this view, overlapping data for the period 1959-61 indicate that our pre1958 measure understated M2 own rates by between 0.27 and 0.29 percentage points. To splice the two series, we add the 28 basis point average gap between them for 1959-61 to the pre-1958 raw average M2 yields. The resulting series is plotted in Figure 3. As a check on the splicing, we recalculated the average own rate on M2 using the balance-weighted average yield on currency, commercial (national bank) and thrifts using annually data on weights and 1929-32 
and 1945-61 published data on MSB average share interest rates. The two series are plotted in Appendix Table A1. The resulting difference between this series and official Federal Reserve estimates for the 1959-61 overlap years were between 0.01 and 0.03 percentage points, implying that the splice is reasonable. In addition, the difference between the spliced and MSB-based series was about 0 between 1927 and 1930 and 1956-61, with the MSB series understating the spliced series by between 0.01 and 0.15 percentage points. Because MSB interest rate data are unavailable for 1933-45 and do not fully reflect interest rates offered at other types of thrift institutions, we use the spliced series in Figure 1 as the own rate on M2.

\section{Figure B1: Weighted Average (Own) Interest Rate Paid on M2 Balances}

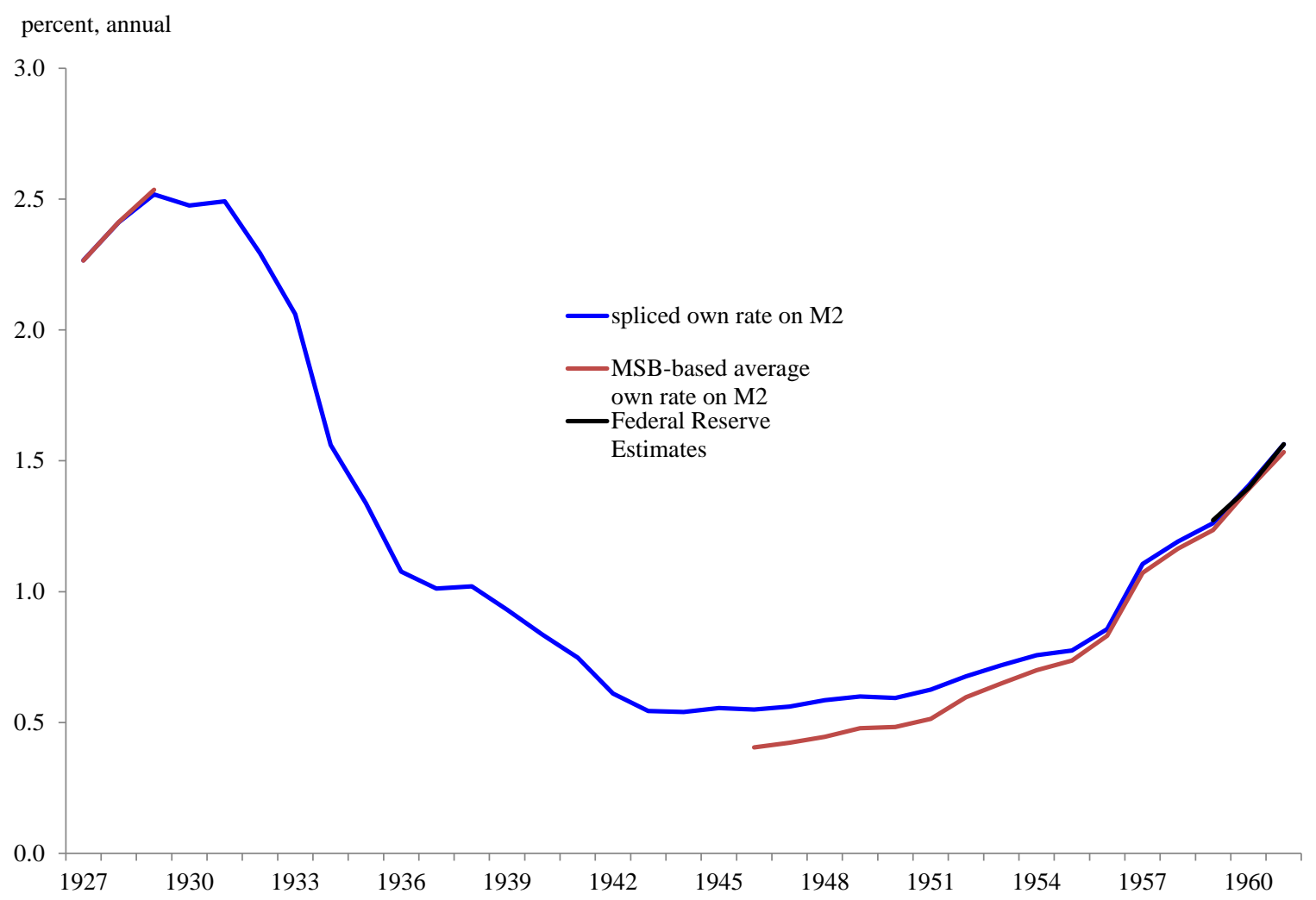


Table 1: Augmented Dickey-Fuller statistics

\begin{tabular}{|c|c|c|c|c|c|c|}
\hline Variable & $\mathrm{m}$ & $\Delta \mathrm{m}$ & $p$ & $\Delta p$ & $\mathrm{y}$ & $\Delta y$ \\
\hline \multirow[t]{2}{*}{ Specification } & Constant & & Constant & & Constant & \\
\hline & Trend & & Trend & & Trend & \\
\hline Longest Lag & 0 & 1 & 0 & 1 & 0 & 1 \\
\hline ADF t-value & -2.52 & -2.72 & -3.31 & -6.07 & -2.48 & -3.36 \\
\hline c.v. $5 \%$ & -3.46 & -1.94 & -3.46 & -2.89 & -3.46 & -1.94 \\
\hline c.v. $1 \%$ & -4.06 & -2.59 & -4.06 & -3.51 & -4.06 & -2.59 \\
\hline Variable & $\mathrm{v}$ & $\Delta v$ & $\mathrm{M} 2 \mathrm{OC}$ & $\Delta \mathrm{M} 2 \mathrm{OC}$ & In(SLoad) & $\Delta \ln$ (Sload) \\
\hline \multirow[t]{2}{*}{ Specification } & Constant & & Constant & & Constant & \\
\hline & Trend & & Trend & & Trend & \\
\hline Longest Lag & 0 & 1 & 0 & 1 & 0 & 1 \\
\hline ADF t-value & -1.60 & -6.62 & -2.84 & -8.74 & -1.89 & -2.71 \\
\hline c.v. $5 \%$ & -3.46 & -1.94 & -3.46 & -1.94 & -3.46 & -1.94 \\
\hline c.v. $1 \%$ & -4.06 & -2.59 & -4.06 & -2.59 & -4.06 & -2.59 \\
\hline Variable & Baa & 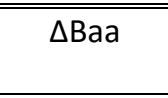 & $\begin{array}{c}\text { Treasury Yield } \\
\text { Long (TR) }\end{array}$ & $\begin{array}{l}\Delta \text { Treasury } \\
\text { yield Long }\end{array}$ & $\begin{array}{c}\text { In(Baa-TR } \\
\text { Long) }\end{array}$ & $\begin{array}{c}\Delta \ln (\text { Baa-TR } \\
\text { long) }\end{array}$ \\
\hline \multirow[t]{2}{*}{ Specification } & Constant & & Constant & & Constant & \\
\hline & Trend & & Trend & & Trend & \\
\hline Longest Lag & 0 & 1 & 0 & 1 & 0 & 1 \\
\hline ADF t-value & -1.10 & -6.56 & -1.23 & -7.44 & -2.65 & -8.84 \\
\hline c.v. $5 \%$ & -3.46 & -1.94 & -3.46 & -1.94 & -3.46 & -1.94 \\
\hline c.v. $1 \%$ & -4.06 & -2.59 & -4.06 & -2.59 & -4.06 & -2.59 \\
\hline Variable & M2 Own Rate & $\begin{array}{c}\Delta \mathrm{M} 2 \text { Own } \\
\text { Rate }\end{array}$ & $\begin{array}{c}\text { Treasury Yield } \\
\text { Short }\end{array}$ & $\begin{array}{l}\Delta \text { Treasury } \\
\text { Yield Short }\end{array}$ & m-p & $\bar{~} \Delta(\mathrm{m}-\mathrm{p})$ \\
\hline Specification & $\begin{array}{l}\text { Constant } \\
\text { Trend }\end{array}$ & & $\begin{array}{c}\text { Constant } \\
\text { Trend }\end{array}$ & & $\begin{array}{l}\text { Constant } \\
\text { Trend }\end{array}$ & \\
\hline Longest Lag & 0 & 1 & 0 & 1 & 0 & 1 \\
\hline ADF t-value & -0.87 & -6.57 & -1.60 & -7.88 & -1.79 & -4.23 \\
\hline c.v. $5 \%$ & -3.46 & -1.94 & -3.46 & -1.94 & -3.46 & -1.94 \\
\hline c.v. $1 \%$ & -4.06 & -2.59 & -4.06 & -2.59 & -4.06 & -2.59 \\
\hline Variable & OCST & YC & $\Delta \mathrm{YC}$ & & & \\
\hline \multirow[t]{2}{*}{ Specification } & Constant & Constant & & & & \\
\hline & Trend & Trend & & & & \\
\hline Longest Lag & 0 & 0 & 1 & & & \\
\hline ADF t-value & -9.06 & -4.07 & -7.76 & & & \\
\hline c.v. $5 \%$ & -3.46 & -3.46 & -1.94 & & & \\
\hline c.v. $1 \%$ & -4.06 & -4.06 & -2.59 & & & \\
\hline
\end{tabular}

Levels variables are in logs. Interest rate variables are in levels except SLoad. $m=M 2, p=G D P$ price deflator, $y=G D P$, $\mathrm{v}=$ velocity of M2, TR=average yield on long-term (10-year) Treasury securities, M2OC=M2own rate minus shortterm Treasury rate, Sload=equity mutual fund front-end load, Baa=Moody's Baa bond yield, OCST=opportunity cost of $\mathrm{M} 2$ relative to stock returns, $\mathrm{YC}=$ yield curve slope equal to yield on long Treasury minus yield on short Treasury bills. 
Table 2: Vector Error Correction Models of Log M2's Velocity

\begin{tabular}{|c|c|c|c|c|c|c|c|c|}
\hline \multicolumn{7}{|c|}{ Long-Run Equilibrium: In $\mathrm{V}_{\mathrm{t}}=\alpha_{0}+\alpha_{1} O C_{\mathrm{t}}+\alpha_{2} \ln S \operatorname{Load}_{\mathrm{t}}+\alpha_{3} \ln \operatorname{BaaTR}_{\mathrm{t}}+\mu_{\mathrm{t}}$} & \multicolumn{2}{|c|}{$\underline{\text { GDI replaces GDP }}$} \\
\hline $\begin{array}{l}\text { Model No. } \\
\text { Variables }\end{array}$ & $\begin{array}{c}1 \\
1932-2014 \\
0857\end{array}$ & $\begin{array}{c}2 \\
1932-2006\end{array}$ & $\begin{array}{c}3 \\
1932-2014 \\
0842\end{array}$ & $\begin{array}{c}4 \\
1932-2014\end{array}$ & $\begin{array}{c}5 \\
1932-2014\end{array}$ & $\begin{array}{c}6 \\
1932-1998\end{array}$ & $\begin{array}{c}7 \\
1932-2014 \\
0.848\end{array}$ & $\begin{array}{c}8 \\
1932-2014 \\
0.481\end{array}$ \\
\hline$O C_{\mathrm{t}}$ & $\begin{array}{l}0.040^{* *} \\
(4.18)\end{array}$ & $\begin{array}{l}0.040^{\text {** }} \\
(3.80)\end{array}$ & $\begin{array}{l}0.047^{* \star} \\
(3.88)\end{array}$ & $\begin{array}{l}0.029 \\
(0.78)\end{array}$ & $\begin{array}{l}0.054^{+} \\
(1.84)\end{array}$ & $\begin{array}{l}0.036^{*} \\
(2.56)\end{array}$ & $\begin{array}{l}0.037^{\text {*x }} \\
(4.01)\end{array}$ & $\begin{array}{l}0.047 \\
(1.68)\end{array}$ \\
\hline In SLoad $\mathrm{t}$ & $\begin{array}{l}-0.190^{* *} \\
(11.88)\end{array}$ & $\begin{array}{l}-0.192^{* *} \\
(10.05)\end{array}$ & $\begin{array}{l}-0.182^{* *} \\
(8.76)\end{array}$ & & & $\begin{array}{l}-0.208^{* *} \\
(3.43)\end{array}$ & $\begin{array}{l}-0.189^{* *} \\
(12.20)\end{array}$ & \\
\hline & $\begin{array}{l}-0.088^{* *} \\
(3.81)\end{array}$ & $\begin{array}{l}-0.092^{* *} \\
(3.62)\end{array}$ & $\begin{array}{l}-0.101^{* *} \\
(3.38)\end{array}$ & $\begin{array}{r}-0.060 \\
(0.62)\end{array}$ & & $\begin{array}{l}-0.091^{* *} \\
(2.88)\end{array}$ & $\begin{array}{l}-0.078^{*}{ }^{*} \\
(3.48)\end{array}$ & \\
\hline unique coint. & Yes ${ }^{* *}$ & $\mathrm{Yes}^{* *}$ & Yes & No & Yes $^{*}$ & Yes*t & Yes $^{* *}$ & Yes* \\
\hline o vec. & 84.03 & 73.17 & $64.7 \mathrm{~s}$ & 24.7 & 19.1 & 69.2 & $91.13^{\star *}$ & 21.34 \\
\hline trace only 1 & 25.14 & 21.63 & 26.85 & 6.72 & 2.51 & 25.28 & 25.00 & 2.21 \\
\hline \multicolumn{9}{|c|}{ Short-Run: $\Delta V 2_{\mathrm{t}}=\beta_{0}+\beta_{1} E C_{\mathrm{t}-1}+\Sigma \beta_{2 i} \Delta O C_{\mathrm{t}-\mathrm{i}}+\Sigma \beta_{3 \mathrm{i}} \Delta S \operatorname{Soad}_{\mathrm{t}-\mathrm{i}}+\Sigma \beta_{4 \mathrm{i}} \Delta$ BaaTR $_{\mathrm{t}-\mathrm{i}}+$ Other S-Run Factors $\mathrm{s}_{\mathrm{t}}+\varepsilon_{\mathrm{t}}$} \\
\hline $\begin{array}{l}E C_{\mathrm{t}-1,} \\
\text { 'adjust.speed' }\end{array}$ & $\begin{array}{c}-0.320^{\star *} \\
(5.27)\end{array}$ & $\begin{array}{l}-0.324^{* *} \\
(4.95)\end{array}$ & $\begin{array}{l}-0.288^{* *} \\
(4.48)\end{array}$ & $\begin{array}{c}-0.096^{* *} \\
(3.55)\end{array}$ & $\begin{array}{l}-0.105^{* *} \\
(3.32)\end{array}$ & $\begin{array}{l}-0.295^{* *} \\
(4.44)\end{array}$ & $\begin{array}{l}-0.321^{* *} \\
(5.55)\end{array}$ & $\begin{array}{l}-0.108^{\star *} \\
(3.49)\end{array}$ \\
\hline$O C S T_{\mathrm{t}-1} \times 100$ & $\begin{array}{c}-0.071^{* *} \\
(3.74)\end{array}$ & $\begin{array}{l}-0.072^{* *} \\
(3.55)\end{array}$ & $\begin{array}{c}-0.082^{* *} \\
(4.14)\end{array}$ & $\begin{array}{l}-0.081^{* *} \\
(4.14)\end{array}$ & $\begin{array}{l}-0.089^{* *} \\
(5.04)\end{array}$ & $\begin{array}{l}-0.088^{* *} \\
(3.83)\end{array}$ & $\begin{array}{r}-0.070^{* *} \\
(3.62)\end{array}$ & $\begin{array}{c}-0.087^{\text {** }} \\
(4.85)\end{array}$ \\
\hline$Y C_{\mathrm{t}-1} \times 100$ & $\begin{array}{l}0.708^{+} \\
(1.72)\end{array}$ & $\begin{array}{l}0.799^{+} \\
(1.78)\end{array}$ & $\begin{array}{l}0.653 \\
(1.56)\end{array}$ & $\begin{array}{l}0.770^{+} \\
(1.71)\end{array}$ & $\begin{array}{l}0.607 \\
(1.43)\end{array}$ & $\begin{array}{l}0.481 \\
(0.95)\end{array}$ & $\begin{array}{l}0.520 \\
(1.27)\end{array}$ & $\begin{array}{l}0.540 \\
(1.25)\end{array}$ \\
\hline BankHoliday $y_{\mathrm{t}}$ & $\begin{array}{l}0.074^{*} \\
(2.34)\end{array}$ & $\begin{array}{l}0.059^{+} \\
(1.70)\end{array}$ & & $\begin{array}{l}0.070^{*} \\
(2.04)\end{array}$ & $\begin{array}{l}0.088^{* *} \\
(2.80)\end{array}$ & $\begin{array}{l}0.042 \\
(1.11)\end{array}$ & $\begin{array}{l}0.069^{*} \\
(2.24)\end{array}$ & $\begin{array}{l}0.085^{* *} \\
(2.75)\end{array}$ \\
\hline DeflationPCE $E_{\mathrm{t}}$ & $\begin{array}{l}-0.047^{\text {t* }} \\
(3.38)\end{array}$ & $\begin{array}{l}-0.047^{* *} \\
(3.06)\end{array}$ & & $\begin{array}{l}-0.048^{* *} \\
(3.21)\end{array}$ & $\begin{array}{l}-0.041^{* *} \\
(3.03)\end{array}$ & $\begin{array}{l}-0.042^{*} \\
(2.55)\end{array}$ & $\begin{array}{l}-0.053^{* *} \\
(3.78)\end{array}$ & $\begin{array}{c}-0.046^{* *} \\
(3.36)\end{array}$ \\
\hline DumAccord $_{\mathrm{t}}$ & $\begin{array}{c}-0.050^{+} \\
(1.89)\end{array}$ & $\begin{array}{l}-0.049^{+} \\
(1.74)\end{array}$ & & $\begin{array}{r}-0.036 \\
(1.29)\end{array}$ & $\begin{array}{r}-0.027 \\
(0.98)\end{array}$ & $\begin{array}{l}-0.054^{+} \\
(1.87)\end{array}$ & $\begin{array}{l}-0.057^{*} \\
(2.14)\end{array}$ & $\begin{array}{r}-0.032 \\
(1.13)\end{array}$ \\
\hline$D M M D A_{t}$ & $\begin{array}{l}-0.034 \\
(1.27)\end{array}$ & $\begin{array}{r}-0.034 \\
(1.18)\end{array}$ & & $\begin{array}{r}-0.019 \\
(0.69)\end{array}$ & $\begin{array}{r}-0.037 \\
(1.42)\end{array}$ & $\begin{array}{r}-0.036 \\
(1.22)\end{array}$ & $\begin{array}{l}-0.045^{+} \\
(1.65)\end{array}$ & $\begin{array}{l}-0.045^{+} \\
(1.70)\end{array}$ \\
\hline$D F A_{\mathrm{t}}$ & $\begin{array}{l}-0.070^{* *} \\
(5.03)\end{array}$ & & $\begin{array}{l}-0.066^{* *} \\
(4.52)\end{array}$ & $\begin{array}{c}-0.049^{* x} \\
(3.25)\end{array}$ & $\begin{array}{l}-0.053^{\text {** }} \\
(3.56)\end{array}$ & & $\begin{array}{l}-0.064^{\text {** }} \\
(4.73)\end{array}$ & \\
\hline Dum1941 & $\begin{array}{l}0.088^{\text {** }} \\
(3.55)\end{array}$ & $\begin{array}{l}0.087^{\text {** }} \\
(3.24)\end{array}$ & $\begin{array}{l}0.102^{* *} \\
(3.78)\end{array}$ & $\begin{array}{l}0.095^{\star *} \\
(3.43)\end{array}$ & $\begin{array}{l}0.089^{*} \\
(3.30)\end{array}$ & $\begin{array}{l}0.092^{* *} \\
(3.34)\end{array}$ & $\begin{array}{l}0.086^{\text {** }} \\
(3.42)\end{array}$ & $\begin{array}{l}0.087^{*} \\
(3.18)\end{array}$ \\
\hline Dum1942 & $\begin{array}{l}0.108^{* *} \\
(3.85)\end{array}$ & $\begin{array}{l}0.113^{\text {*t }} \\
(3.74)\end{array}$ & $\begin{array}{l}0.128^{* *} \\
(4.19)\end{array}$ & $\begin{array}{l}0.088^{* *} \\
(2.90)\end{array}$ & $\begin{array}{l}0.113^{\text {*t }} \\
(4.08)\end{array}$ & $\begin{array}{l}0.110^{* *} \\
(3.61)\end{array}$ & $\begin{array}{l}0.116 \\
(4.13)\end{array}$ & $\begin{array}{l}0.121^{* \star} \\
(4.33)\end{array}$ \\
\hline Dum1943 ${ }_{\mathrm{t}}$ & $\begin{array}{r}-0.036 \\
(1.37)\end{array}$ & $\begin{array}{r}-0.034 \\
(1.23)\end{array}$ & $\begin{array}{r}-0.017 \\
(0.59)\end{array}$ & $\begin{array}{c}-0.063^{*} \\
(2.28)\end{array}$ & $\begin{array}{c}-0.055^{\star} \\
(2.00)\end{array}$ & $\begin{array}{r}-0.037 \\
(1.32)\end{array}$ & $\begin{array}{r}-0.036 \\
(1.35)\end{array}$ & $\begin{array}{r}-0.053^{+} \\
(1.89)\end{array}$ \\
\hline Dum1944t & $\begin{array}{c}-0.061^{*} \\
(2.41)\end{array}$ & $\begin{array}{c}-0.062^{*} \\
(2.33)\end{array}$ & $\begin{array}{c}-0.056^{*} \\
(2.03)\end{array}$ & $\begin{array}{c}-0.072^{*} \\
(2.60)\end{array}$ & $\begin{array}{c}-0.079^{\text {** }} \\
(2.93)\end{array}$ & $\begin{array}{r}-0.057^{\star} \\
(2.14)\end{array}$ & $\begin{array}{c}-0.076^{\text {** }} \\
(3.01)\end{array}$ & $\begin{array}{c}-0.095^{\text {* }} \\
(3.46)\end{array}$ \\
\hline Dum1945t & $\begin{array}{c}-0.170^{* *} \\
(6.46)\end{array}$ & $\begin{array}{c}-0.172^{* *} \\
(6.23)\end{array}$ & $\begin{array}{c}-0.172^{\text {** }} \\
(5.99)\end{array}$ & $\begin{array}{c}-0.170^{* *} \\
(5.86)\end{array}$ & $\begin{array}{c}-0.182^{\text {** }} \\
(6.49)\end{array}$ & $\begin{array}{c}-0.166^{* *} \\
(5.91)\end{array}$ & $\begin{array}{c}-0.172^{\star *} \\
(6.34)\end{array}$ & $\begin{array}{c}-0.187^{\star *} \\
(6.42)\end{array}$ \\
\hline
\end{tabular}




\begin{tabular}{llllllrrr} 
Dum1946 & $-0.090^{* *}$ & $-0.098^{* *}$ & $-0.108^{* *}$ & $-0.073^{*}$ & $-0.084^{*}$ & $-0.100^{*}$ & $\begin{array}{r}-0.083^{*} \\
(2.54)\end{array}$ & $\begin{array}{r}-0.080^{*} \\
(2.28)\end{array}$ \\
\hline Adj. R ${ }^{2}$ & $(2.71)$ & $(2.66)$ & $(3.06)$ & $(2.04)$ & $(2.36)$ & $(2.65)$ & 0.770 & 0.708 \\
S.E. x 100 & 0.754 & 0.724 & 0.696 & 0.699 & 0.694 & 0.737 & 0.770 \\
VEC Auto (1) & 15.155 & 2.249 & 2.395 & 2.383 & 2.402 & 2.266 & 2.157 & 2.429 \\
VEC Auto (2) & 24.23 & 15.16 & 18.89 & 11.75 & 7.44 & 13.80 & 15.87 & 5.82 \\
VEC Auto (4) & 13.25 & 21.50 & $31.01^{\text {** }}$ & 15.78 & 6.47 & 20.87 & 23.76 & 5.19 \\
\hline
\end{tabular}

Notes: (i) Absolute t-statistics are in parentheses. ${ }^{* *}\left({ }^{*}\right)$ denotes significant at the $99 \%$ (95\%) confidence level.

VECLM significance levels vary

with the size of the cointegrating vector.

(ii) Long-run: Maximum likelihood estimates of the long-run equilibrium relationship:

In $V_{2}=\alpha_{0}+\alpha_{1} O C_{t}+\alpha_{2} \ln S_{L o a d}+\alpha_{3} \ln$ BaaTR $_{\mathrm{t}}$

$+\mu_{\mathrm{t}}$ using a four equation system with (at most) one cointegrating vector.

(iii) Short-run: OLS estimates of the speed of adjustment and short-run dynamics using the estimated equilibrium correction terms in (ii),

$E C_{\mathrm{t}-1}=$ CapRate $_{\mathrm{t}-1}-\alpha_{0}-\alpha_{1} O C_{\mathrm{t}-1}-\alpha_{2} \ln$ SLoad $_{\mathrm{t}-1}-\alpha_{3} \ln$ BaaTR $_{\mathrm{t}-1}$

(iv) Lagged first difference terms of elements in the long-run cointegrating vector and the constant in the short-run model are omitted to conserve space.

(v) Lag lengths chosen to obtain unique significant vectors with sensible coefficients and clean residuals.

Equal to 4 in all models.

(vi) Augmented Dickey Fuller (ADF) unit root tests statistics are below. The data used cover 1996q1 to $2013 q 4$.

The lag lengths in the ADF regressions, which included a constant, were selected based on the SIC. 


\section{Appendix C: Projected Paths of Key Determinants of V2 for Simulations}

and In-Sample Model Residuals

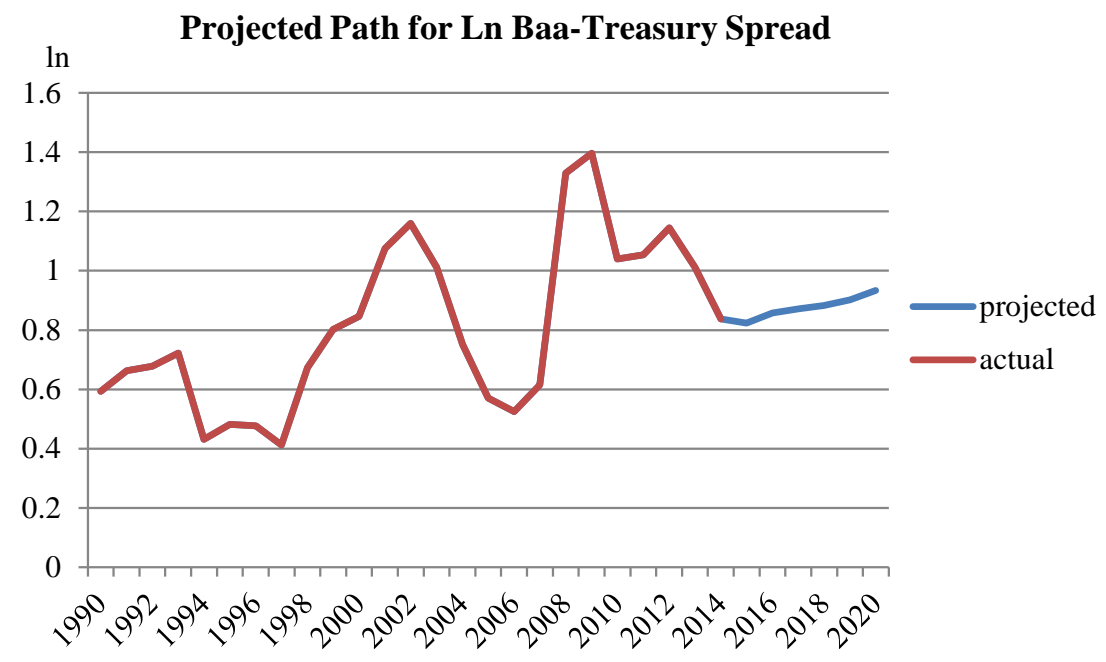

Projected Path for Conventional M2 Opportunity Cost $\%$ pts.
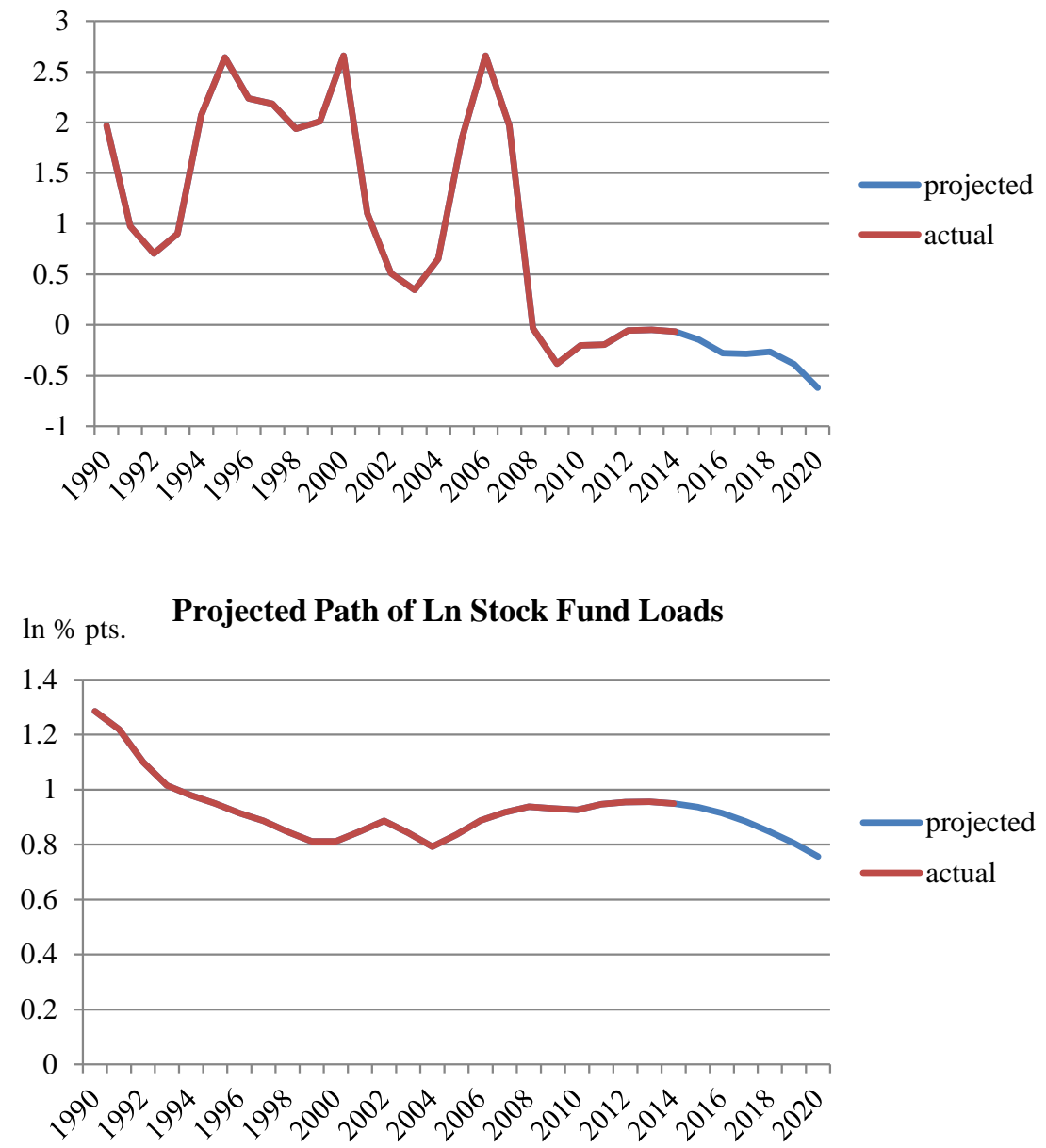
Second Stage Residuals for the first difference of logs of several main V2 determinants, each of which are clean.
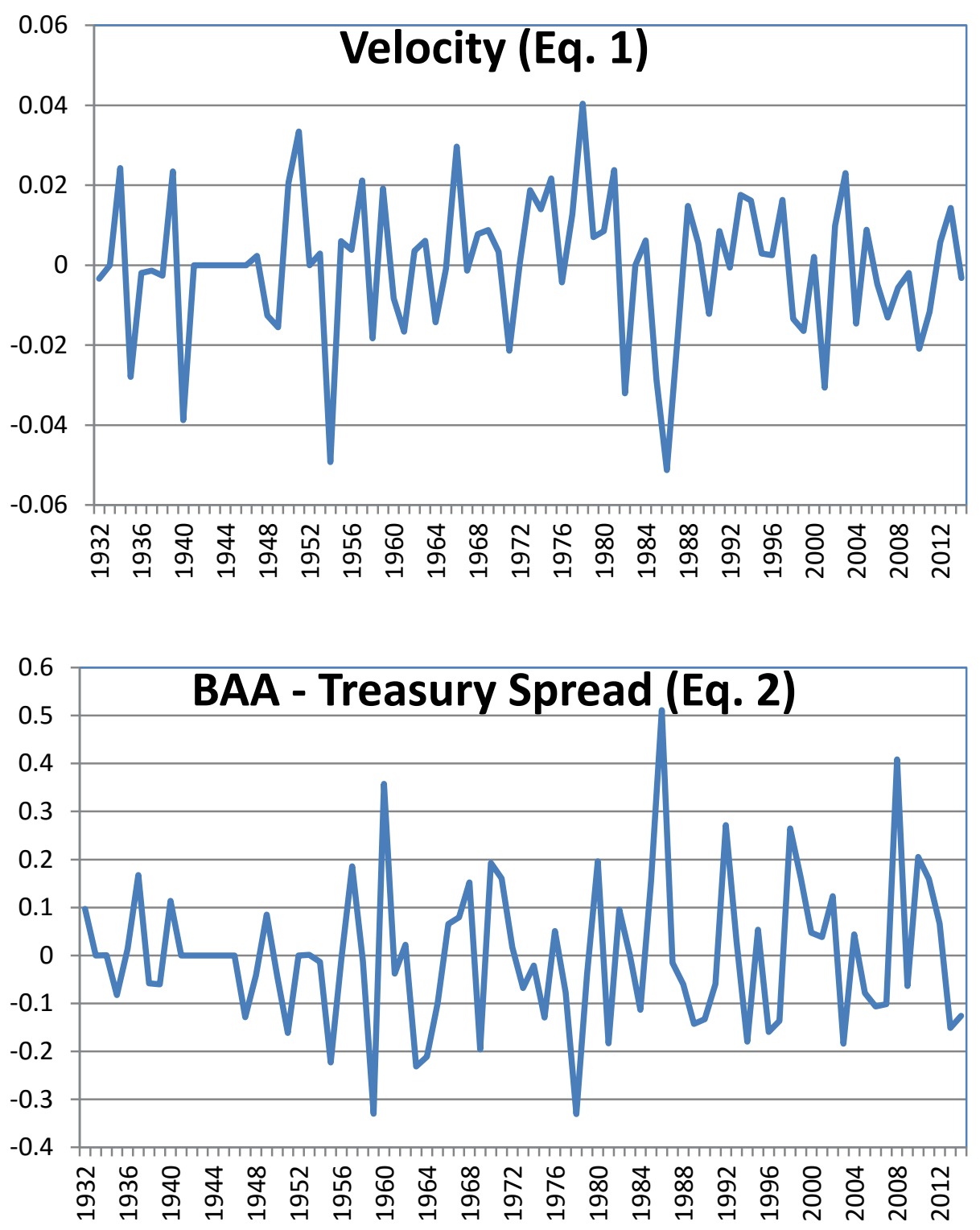

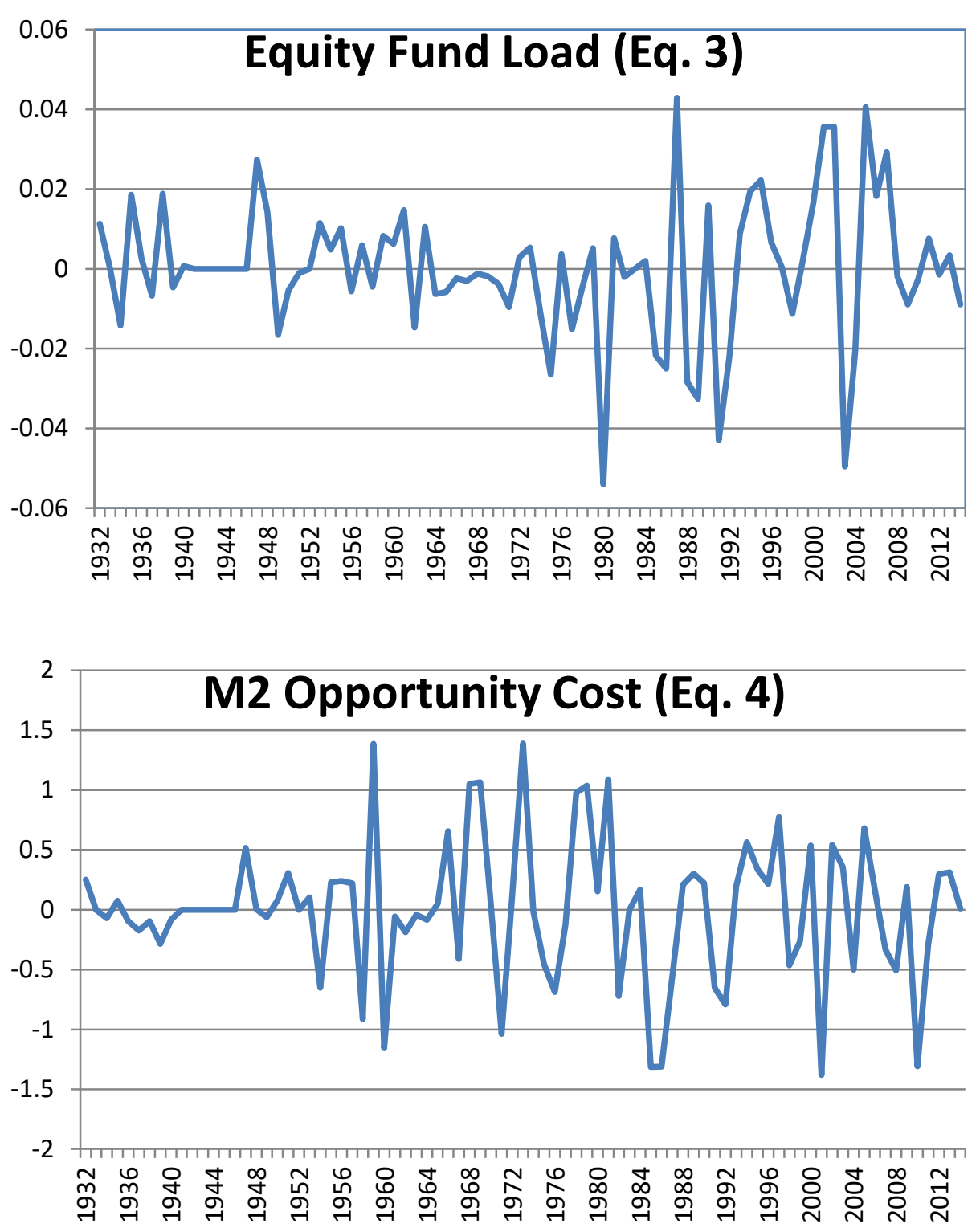